\title{
A EDUCAÇÃO INFANTIL NA PERSPECTIVA DE GESTORES, DE PROFESSORES E DE PAIS.
}

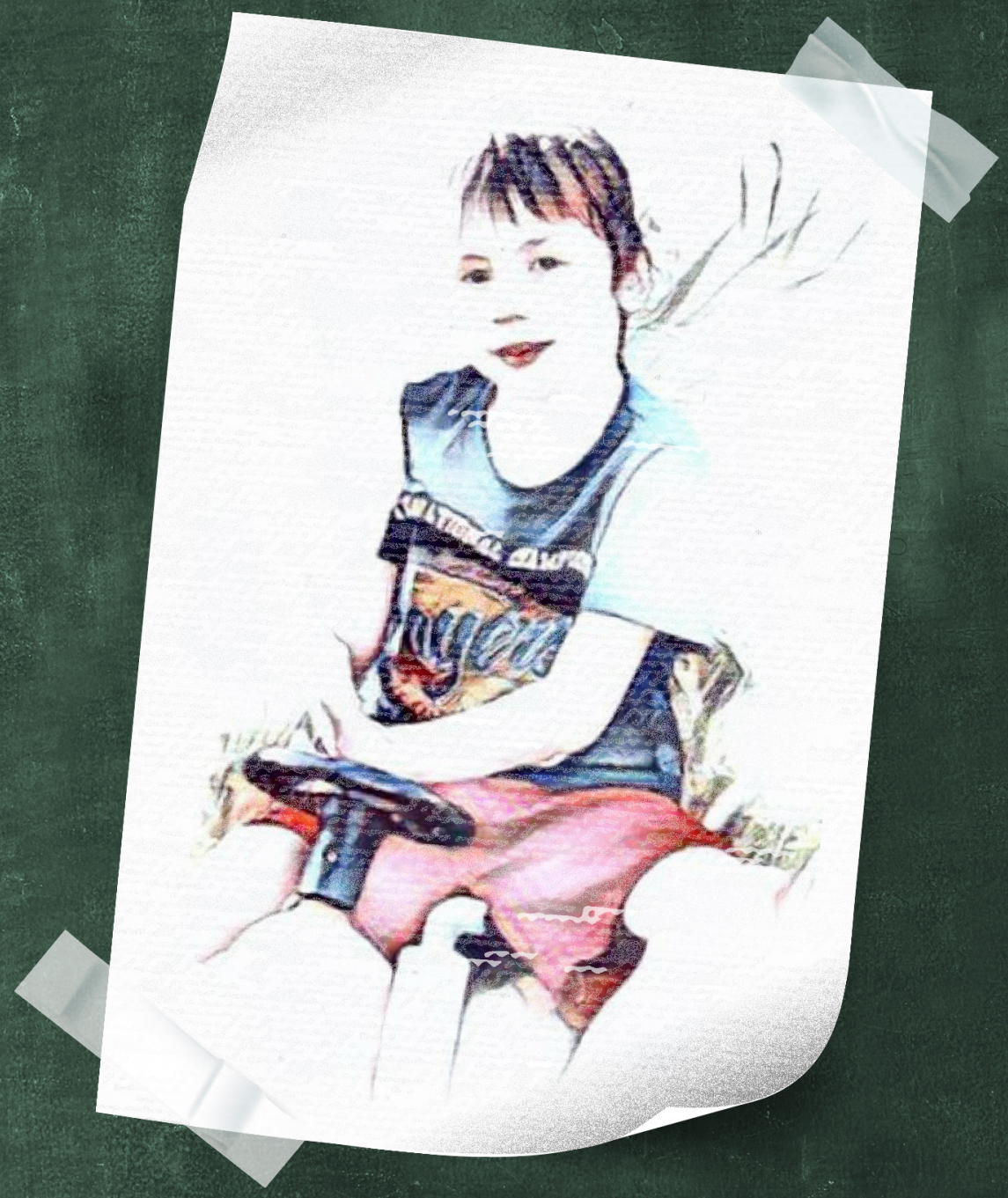

MARIA ELEUSA MONTENEGRO (ORGANIZAÇÃO) ANA REGINA MELO SALVIANO - JEAN CARMO BARBOSA ELIETE DE PINHO ARAUJO • MARCELA FARIA MARTINS SILVA

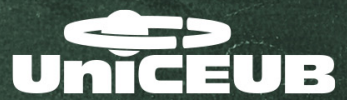




\section{Organização}

\section{Maria Eleusa Montenegro}

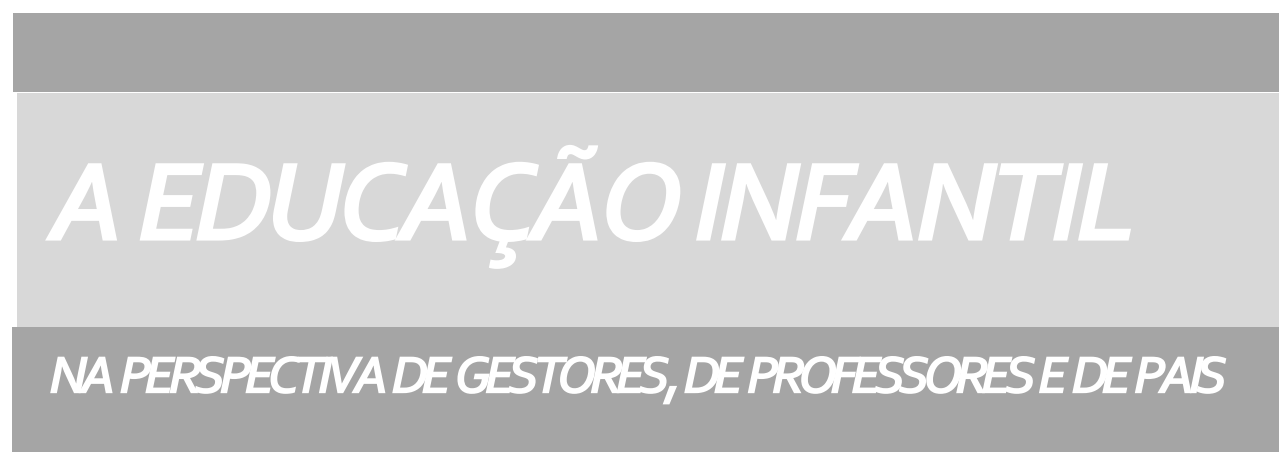

Ana Regina Melo Salviano

Jean Carmo Barbosa

Eliete de Pinho Araujo

Marcela Faria Martins Silva

\section{Brasília}

2020 


\section{CENTRO UNIVERSITÁRIO DE BRASÍLIA - UniCEUB}

\section{Reitor}

Getúlio Américo Moreira Lopes

\section{INSTITUTO CEUB DE PESOUISA E DESENVOLVIMENTO - ICPD}

\section{Diretor}

João Herculino de Souza Lopes Filho

Diretor Técnico

Rafael Aragão Souza Lopes

\section{EQUIPE EDITORIAL}

Coordenação geral acadêmica

Prof. Dra. Maria Eleusa Montenegro

Comissão técnico-científica

1. Dra. Maria Eleusa Montenegro, Centro Universitário de Brasília, Brasília/DF, Brasil

2. Sonia da Cunha Urt, Universidade Federal de Mato Grosso do Sul, Campo Grande/MS, Brasil

3. Colandi Carvalho de Oliveira, Mestre em Educação, Brasília/DF, Brasil

4 Maria das Dores Brigagão, Pós-Graduação em Matemática, UniCEUB, Brasília/DF, Brasil

\section{Grupo de pesquisa}

"Prática Pedagógica e Formação de Professores"

\section{Avaliação por pares}

\section{Diagramação}

Biblioteca Reitor João Herculino

\section{Capa \\ UniCEUB}

Documento disponível no link

https://repositorio.uniceub.br/jspui/handle/prefix/14118

\section{Dados Internacionais de Catalogação na Publicação (CIP)}

A educação infantil na perspectiva de gestores, de professores e de pais / Maria Eleusa Montenegro (organizadora); Ana Regina Melo Salviano; Jean Carmo Barbosa; Eliete de Pinho Araujo; Marcela Faria Martins Silva - Brasília: UniCEUB, 2020. $94 \mathrm{P}$.

ISBN 978-65-00-03075-4

1. Educação infantil. I. Centro Universitário de Brasília. II. Título.

CDU 372.3

Ficha catalográfica elaborada pela Biblioteca Reitor João Herculino 


\section{SOBRE OS AUTORES}

\section{MARIA ELEUSA MONTENEGRO}

Mestre e doutora em Educação pela UNICAMP/SP (área de concentração em Psicologia da Educação); pós-doutora pela Faculdade de Educação da Universidade de Brasília (UnB); professora aposentada da Faculdade de Educação da Universidade Federal de Goiás (UFG); professora substituta da Faculdade de Educação da UnB; professora da disciplina Docência do Ensino Superior e Compromisso Social do curso de Mestrado de Arquitetura e Urbanismo e dos cursos de Licenciaturas do Centro Universitário de Brasília (UniCEUB). E-mail: maria.montenegro@ceub.edu.br

\section{ANA REGINA MELO SALVIANO}

Mestre em Educação pela Faculdade de Educação da Universidade de Brasília (UnB, Currículo e Metodologia de Ensino); pedagoga; orientadora educacional; administradora escolar; professora aposentada da Secretaria de Educação do Distrito Federal; professora do Centro Universitário de Brasília (UniCEUB), coordenadora da pós-graduação em Docência do Ensino Superior e responsável pelo atendimento educacional especializado nessa mesma Instituição. Email: ana_regina@terra.com.br

\section{JEAN CARMO BARBOSA}

Mestrando em Poder Legislativo, Pedagogo e gestor público. Foi administrador Regional de Brasília e de São Sebastião. Coordenou o Centro Universitário de Cultura e Arte da Une na UnB. Presidiu a União da Juventude Socialista no DF. Atualmente ocupa o cargo de assessor parlamentar na Câmara dos Deputados. Colunista do Agenda Capital.E-mail: jeancarmo@gmail.com 


\section{ELIETE DE PINHO ARAUJO}

Normalista pela Escola Instituto de Educação - RJ, arquiteta pela FAUUFRJ, Licenciatura pela Faculdade Dom Bosco - BSB, Mestre em Planejamento Urbano - Tecnologia FAU - UnB, Doutora em Saúde Pública, ENSP - FIOCRUZ (Capes nível 6), Pós-doutora pela Universidade da Coruña. Arquiteta da Secretaria de Saúde SES-DF, Professora do Curso de Arquitetura e Urbanismo, FATECS UniCEUB. Coordenadora do Mestrado em Arquitetura e Urbanismo do ICPD UniCEUB. E-mail: eliete.araujo@ceub.edu.br

\section{MARCELA FARIA MARTINS SILVA}

Graduada em Comunicação Social com habilitação em publicidade e propaganda pelo Instituto de Educação Superior de Brasília (IESB). Cursando atualmente Pedagogia na Universidade Paulista (UNIP). Professora assistente de Educação Infantil na Escola Canadense de Brasília. Participou do 1 Encontro de Neuroeducação e Psicopedagogia em Brasília e é professora voluntária de inglês para alunos de escola pública da Cidade da Estrutural. E-mail: marcelaf.martinss14@gmail.com 


\section{RESUMO}

Este livro é fruto do trabalho do Grupo de Pesquisa "Prática Pedagógica e Formação de Professores”, existente desde 2004, registrado no Centro Universitário de Brasília (UniCEUB) e cadastrado no Conselho Nacional de Desenvolvimento Científico e Tecnológico (CNPq). Este grupo tem realizado várias pesquisas na área educacional, dentre elas na Educação Infantil. Este livro é o resultado de entrevistas com professores, gestores e pais de alunos deste nível de ensino, tanto de escolas públicas quanto das particulares. Acredita-se que a sua riqueza de dados se constitui em seu ponto alto. Espera-se que ele possa contribuir com todos os envolvidos e interessados na área.

\section{ABSTRACT}

This book is the result of the effort of the Research Group "Prática Pedagógica e Formação de Professores”, existing since 2004, registered at the Centro Universitário de Brasília (UniCEUB) and at the Conselho Nacional de Desenvolvimento Científico e Tecnológico (CNPq). This group has carried out several kinds of research in the educational area, with Early Childhood Education among them. This book is the result of interviews with teachers, managers, and parents of students at this level of education, both from public and private schools. It is believed that the book's highlight is its wealth of data. Hopefully, the book will contribute to all the involved and interested people in the field.

\section{RESUMEN}

Este libro es el resultado del trabajo del Grupo de Investigación "Prática Pedagógica e Formação de Professores”, existente desde 2004, registrada en el Centro Universitário de Brasília (UniCEUB) y registrada en el Conselho Nacional de Desenvolvimento Científico e Tecnológico (CNPq). Este grupo ha realizado varias investigaciones en el área educativa, entre ellas en Educación Infantil. Este libro es el resultado de entrevistas con maestros, gerentes y padres de estudiantes en este nivel de educación, tanto de escuelas públicas como privadas. Se cree que su gran cantidad de datos es constituye en su punto más alto. Se espera que pueda contribuir con todos involucrado e interesado en el área. 
Agradecimentos especiais às seguintes pessoas, que nos ajudaram na coleta dos dados da pesquisa e nos trabalhos individuais:

Aictyr Lomonte da Silva

Celeida B. Garcia Cintra Pinto

Colandi Carvalho de Oliveira

Dulce Regina de Souza

Elenice Ribeiro dos Santos

Márcia Marins Batista

Marianna Dantas Guimarães de Melo

Silvana Maria Silva Iunes

Simone Áurea S. de Matos 
Dedicamos aos nossos filhos, que também nos ajudaram a compreender a Educação Infantil.

In Memoriam: Ao Arthur Araújo Carmo Barbosa, filhinho do autor Jean, e falecido no decorrer da elaboração desta obra. 
É com prazer que faço a apresentação desta obra. Isto, principalmente por dois motivos: o primeiro, por ter a formação pedagógica e por ter tido a minha história sempre marcada pelo magistério, inclusive na Educação Básica. O segundo motivo é que, por ter me ingressado no Grupo de Pesquisa Prática Pedagógica e Formação de Professores (grupo de pesquisa que está lançando este livro), estou tendo mais uma oportunidade de aprender, pesquisar, conviver e publicar. Com um olhar científico e acadêmico, participamos e apresentamos trabalhos em congressos e eventos de pesquisa, dentro desta área, além de arquitetura e urbanismo.

A partir da formação de grupos de pesquisa, desenvolve-se pesquisas de iniciação científica, de graduação e de pós-graduação (inclusive de mestrado). O grupo fortalece nossa formação e nos proporciona e aos alunos, participação ativa nas pesquisas, dando-nos oportunidades de produção de conhecimento e de formação profissional. A pesquisa acadêmica tem ritmos próprios, sendo por natureza um trabalho colaborativo, pois cada pessoa tem um modo de ver e de sentir a realidade. Por isso a importância da parceria.

Somos todos professores, educadores, pesquisadores e disseminadores de informações pedagógicas (Educação Infantil, Educação Básica, Educação Superior e Mestrado). Dentre as várias conquistas acadêmicas, o lançamento dessa obra amplia o acervo de livros publicados e mostra o olhar pedagógico, contribuindo para a produção de conteúdo na área de educação.

A proposta do livro, com material acerca da área da Educação Infantil, tem como ponto alto a produção de dados oriundos de professores, gestores e pais ligados a esse nível de ensino. Ele foi o esforço de muitos profissionais, a maioria do UniCEUB, na coleta de dados, na publicação de parte da pesquisa e do livro.

Entende-se que a Educação Infantil em nosso país é a entrada da criança na creche ou na escola e representa a primeira experiência de convívio e socialização, fora do contexto familiar. Neste sentido, a escola passa a ser um ambiente de 
conhecimento diferente, de experiências e ampliação de capacidades e habilidades, a partir de aprendizagens variadas como autonomia, comunicação, relacionamento interpessoal e comunicação, para que o respeito mútuo possa ser construído de forma individual e coletiva no desenvolvimento das crianças.

A Educação Infantil é uma fase muito importante na vida do indivíduo, que o prepara para a aprendizagem formal, que o acompanhará por toda a sua vida. Uma criança bem preparada do ponto de vista de suas habilidades para a alfabetização, de sua socialização, da ética e do ponto de vista emocional já terá meio caminho andado em sua escolarização futura.

Profa. Dra. Eliete de Pinho Araujo Centro Universitário de Brasília (UniCEUB) 


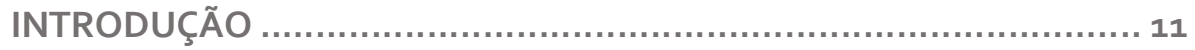

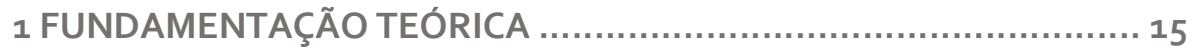

$1.1 \mathrm{O}$ avanço da legislação e das políticas públicas referentes às creches

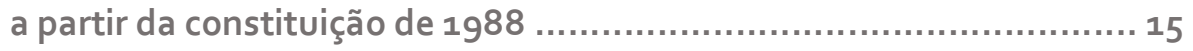

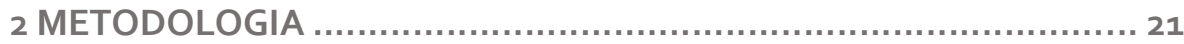

3 A EDUCAÇÃO INFANTIL NA VISÃO DOS PROFESSORES ................ 23

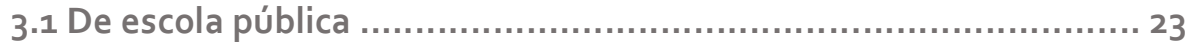

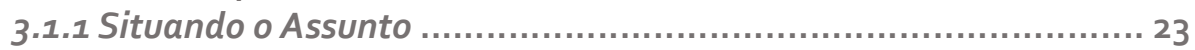

3.1.2 Análise e Discussão dos Dados: principais resultados ................... 24

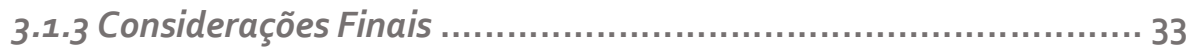

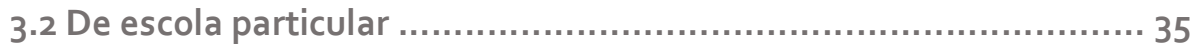

3.2.1 Situando o Assunto .............................................................. 35

3.2.2 Análise e discussão dos dados: principais resultados .................. 36

3.2 .3 Considerações finais ......................................................... 45

4 O GESTOR DA EDUCAÇÃO INFANTIL ........................................... 48

4.1 De escolas públicas e particulares ............................................. 48

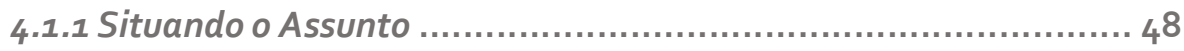

4.1.2 Análise e discussão dos dados: principais resultados ....................50

4.1.3 Considerações finais .................................................... 63

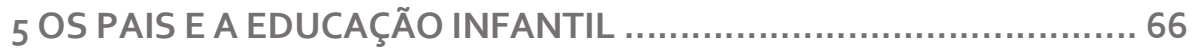

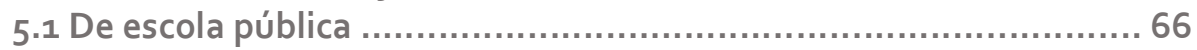

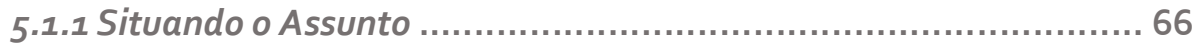

5.1.2 Análise e discussão dos dados: principais resultados ....................68

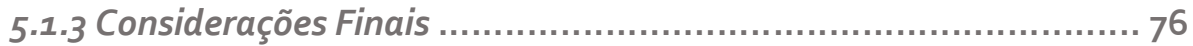

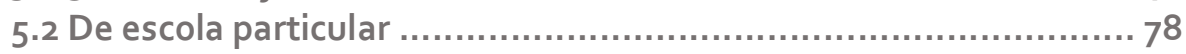

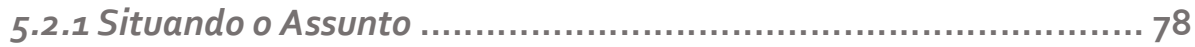

5.2.2 Análise e discussão dos dados: principais resultados ................... 80

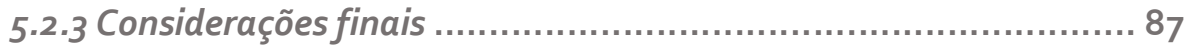

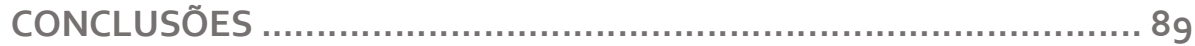

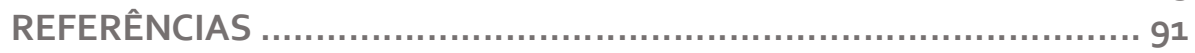




\section{INTRODUÇÃO}

É com muito orgulho e imensa alegria que se apresenta o livro sobre a "Educação Infantil na perspectiva de gestores, de professores e de pais das escolas públicas e particulares." Esta obra é resultado do trabalho e da convivência profissional do Grupo de Pesquisa "Prática Pedagógica e Formação do Professor" que proporcionou um mergulho teórico, ampliação do conhecimento voltado para a realidade, aprofundamento sobre o comprometimento do ensinar e do aprender na Educação Infantil.

Como temática, é instigante, porque é o início da base educacional para as demais modalidades da educação em nosso país. É notório, que é uma das mais complexas fases, de todo o desenvolvimento humano, pois envolve o campo emocional, intelectual, social e motor do mundo infantil. Observa-se que é nos primeiros anos de vida que as crianças constroem as estruturas básicas do ato de pensar e raciocinar, iniciam-se os princípios dos mecanismos de ação e interação com a família com o meio ambiente e, posteriormente, com a sociedade, surgindo, mais tarde, a noção da própria identidade.

Portanto, percebe-se que, o grande desafio colocado a todos que atuam na Educação Infantil é compreender, conhecer e reconhecer o jeito particular das crianças de serem e estarem no mundo.

Quase sempre a entrada na creche ou na escola de Educação Infantil representa a primeira experiência de socialização da criança fora do contexto familiar. A escola passa a ser um ambiente de aprendizagem e ampliação de conhecimentos e habilidades, a partir de aprendizagem com autonomia, comunicação, e o respeito ao outro.

Neste sentido, torna-se fundamental durante o período de Educação Infantil, o compartilhamento de responsabilidades entre as duas instâncias educativas: escola e família.

Por outro lado, e por isso mesmo, esse tipo de publicação estimula novos horizontes e alguns maravilhosos desafios considerados teórico-metodológicos, cuja 
organização propicia um enfrentamento que tem articulado e mobilizado um número crescente de professores e de pesquisadores.

Entretanto, foi escrito também visando analisar, compreender e transformar a visão dos leitores, no que se refere à valorização do professor e de sua formação continuada, sobre a gestão e a organização administrativa, o planejamento pedagógico, as especificidades da aprendizagem dos alunos e o acompanhamento familiar. Também, das formas diversificadas do ler e do escrever para propiciar letramentos ampliados e específicos nas várias áreas do conhecimento e das diferentes e desafiadoras condições do avaliar.

A base legal da Educação Infantil está alicerçada na Constituição de 1988 (BRASIL,1988) que define de forma clara, a responsabilidade do Estado com a educação das crianças de 0 a 6 anos em creches e pré-escolas, entendendo-a como educação não obrigatória, sendo compartilhada com a família. Especificamente, na LDB 9.394/96 (BRASIL.MEC, 1996) os seguintes artigos explicitam suas principais finalidades relativas à Educação infantil:

Art. 29. A educação infantil, primeira etapa da educação básica, tem como finalidade o desenvolvimento integral da criança até seis anos de idade, em seus aspectos físico, psicológico, intelectual e social, complementando a ação da família e da comunidade.

Art. 30. A educação infantil será oferecida em:

I - creches ou entidades equivalentes, para crianças de quatro de até três anos de idade;

II - pré-escolas, para as crianças de quatro a seis anos de idade;

Art. 31. Na educação infantil a avaliação far-se-á mediante acompanhamento e registro do seu desenvolvimento, sem o objetivo de promoção, mesmo para o acesso ao ensino fundamental.

Outro documento é o Referencial Curricular Nacional para a Educação Infantil (BRASIL.MEC, 1998) que orienta, em suas premissas gerais, que se deve considerar que as crianças são diferentes entre si, e que cada uma possui um ritmo de aprendizagem. Por isso, os diretores, coordenadores e professores devem estar preparados para propiciar a todas as crianças uma aprendizagem que atendam às suas características próprias. 
Ressalta-se que, ainda nessa época, a Educação Infantil era considerada uma etapa anterior ao ensino formal, cumprindo a função de preparar os pequenos para o primeiro ano escolar- daí a expressão "pré-escola". Apenas com a promulgação da Lei de Diretrizes e Bases (LDB) (BRASIL.MEC, 1996), ela começa a integrar a Educação Básica e, em 2006, com a modificação introduzida na LDB, que antecipou o ingresso ao Ensino Fundamental para os 6 anos, passou atender a faixa etária de 0 a 5 anos. Vale relembrar que é somente a partir da Emenda Constitucional no 59/2009 (incluída na LDB em 2013) (2011) que a Educação Infantil se torna obrigatória para as crianças de 4 a 5 anos.

Na atualidade, a Educação Infantil está centrada nos pressupostos da Base Nacional Comum Curricular (BNCC) (BRASIL, 2017) nasce com o intuito de equiparar as desigualdades existentes em nosso país, no que se refere aos direitos de aprendizagem, estabelecendo os conhecimentos que devem ser construídos com as crianças de acordo com a fase de desenvolvimento que se encontram.

Neste sentido, uma das funções essenciais das instituições de educação infantil é garantir a socialização, o cuidado e a educação no cotidiano escolar, por meio da interação e da brincadeira, tanto entre a criança e seus pares quanto entre ela e os adultos, como com os objetos, meio ambiente e outros.

Assim, brincando, elas constroem o sentido para o mundo, ampliam e desenvolvem ideias e habilidades, visando compreender conceitos relacionados a cada vivência e ao momento de suas ações.

Na proposta da BNCC (BRASIL, 2017), deve ser papel do educador perceber e monitorar os resultados das ações pedagógicas, a fim de aperfeiçoar suas práticas, sem a intenção de seleção, promoção ou classificação das crianças. Outro ponto importante a ser destacado nessa proposta são os Eixos Estruturantes que envolvem as interações e brincadeiras, para o desenvolvimento de competências gerais previstas como propostas pela BNCC. São Eixos Estruturantes: conviver, brincar, participar, explorar, expressar e se conhecer, e são apresentados em cada um dos eixos os fundamentos essenciais para o desenvolvimento das crianças., em seus direitos de aprendizagem, para que as crianças possam desempenhar um papel ativo na construção de seus conhecimentos. 
Contudo, o resultado destas ações e experiências não devem brotar de um processo natural ou espontâneo, mas resultar de uma prática pedagógica repleta de intencionalidade educativa. Vislumbra-se assim que, à medida que a criança cresce , as aprendizagens se tornem mais complexas e demandem orientações diversificadas. Também, uma organização das trocas e socialização realizadas durante as vivências.

Observa-se ainda, a respeito da BNCC (BRASIL, 2017) que os campos de experiências constituem uma forma de organização curricular adequada à educação Infantil, pois integram as experiências cotidianas da criança com os conhecimentos, em trabalhos interativos, lúdicos, com conteúdos específicos e essenciais para o desenvolvimento da criança. No mundo contemporâneo, as demandas da educação exigem que a organização curricular da Educação Infantil esteja estruturada em cinco campos de experiências, que assim estão organizados: o eu, o outro e o nós; corpo, gestos e movimentos; traços, sons, cores e formas; escuta, fala, pensamento e imaginação; espaços, tempos, quantidades, relações e transformações.

Espera-se, sinceramente que você leitor aproveite este livro e que ele possa atender às suas necessidades acadêmicas e a outros propósitos. Também, que ele possa: dialogar, renovar, transformar, estimular, ajudar a criar, a elaborar, a fazer sorrir, a chorar, e a brincar...

Os autores. 


\section{FUNDAMENTAÇÃO TEÓRICA}

\subsection{O avanço da legislação e das políticas públicas referentes às creches a partir da constituição de 1988}

De uma política elitista e excludente, sem financiamento público, dita de qualidade, a educação migrou no final da década de 1980 para uma política de propósito universalizante, assegurada a todos à luz da Constituição de 1988 (BRASIL, 1988), de natureza laica e pública.

Para que a política educacional assumisse o caráter de um direito subjetivo de todos e um dever do Estado, enquanto ente público, foi fundamental a contribuição do Manifesto dos Pioneiros da Educação Nova, publicado em março de 1932, defendendo a laicidade, gratuidade, obrigatoriedade e coeducação no ensino público (AZEVEDO, 1932).

Os princípios fundantes ou de caráter filosófico contidos nesse manifesto influenciaram profundamente as mudanças ocorridas no curso da história da educação brasileira. A função essencialmente pública da educação, a gratuidade e a laicidade, dentre outros, estão presentes no marco regulatório da política educacional até os dias de hoje, bem como a previsão da coexistência de instituições públicas e privadas, conforme prevê a Carta Magna de 1988, TÍTULO III, Capítulo III, seção I (BRASIL, 1988), e as novas leis que regulamentam os artigos constitucionais, bem como estabelecem as diretrizes nacionais da educação brasileira, como foco na Educação Infantil.

Portanto cabe observar do ponto de vista histórico o aprimoramento da legislação referente ao direito da criança, que ainda é muito recente, no qual pode-se destacar como um primeiro marco legal significativo que influencia a educação infantil a "Declaração dos Direitos da Criança" (ONU, 1959), adotada pela Assembleia das Nações Unidas de 20 de novembro de 1959 e ratificada pelo Brasil, pelo art. 84, inciso XXI, da Constituição Federal de 1988 (BRASIL, 1988), ao qual prevê em seu sétimo princípio:

A criança terá direito a receber educação, que será gratuita e compulsória pelo menos no grau primário. Ser-lhe-á propiciada uma educação capaz de promover a sua cultura 
geral e capacitá-la a, em condições de iguais oportunidades, desenvolver as suas aptidões, sua capacidade de emitir juízo e seu senso de responsabilidade moral e social.[...]. A criança terá ampla oportunidade para brincar e divertir-se, visando os propósitos mesmos da sua educação; a sociedade e as autoridades públicas empenhar-se-ão em promover o gozo deste direito. (ONU, 1959, p. 2)

O documento apresenta um novo percurso histórico da educação infantil, apontando nova visão na elaboração das políticas públicas sobre o tema. Conforme aponta Medeiros et al (apud MORGAN et al., 2014) a educação infantil foi consequência de uma série de transformações econômicas, políticas e sociais ocorridas no país durante o século XX, caracterizadas principalmente pela valorização da mulher e sua inserção no mercado de trabalho, gerando assim, a necessidade de um espaço no qual a criança fosse cuidada e educada.

Assim, a Constituição Federal de 1998 (BRASIL, 1988) e demais legislações, que se aponta a seguir, fundam-se como marcos voltados para a concretização do direito à educação, inserida nesse direito à educação infantil ao recepcionar o texto da Declaração dos Direitos da Criança, apontando um novo olhar sobre a infância e a educação infantil. Anteriormente, a visão do trabalho realizado com as crianças, sobretudo pobres, possuía um cunho assistencial cuja preocupação era a alimentação, a higiene e a segurança física, não valorizando o desenvolvimento cognitivo e afetivo e o trabalho voltado para o desenvolvimento integral da criança (AGUIAR, 2009, p. 32). Aponta-se os dois principais artigos do texto da Constituição Federal de 1998:

Art. 208. O dever do Estado com a educação será efetivado mediante a garantia de:

IV - educação infantil, em creche e pré-escola, às crianças até 5 (cinco) anos de idade;

Art. 227. É dever da família, da sociedade e do Estado assegurar à criança, ao adolescente e ao jovem, com absoluta prioridade, o direito à vida, à saúde, à alimentação, à educação, ao lazer, à profissionalização, à cultura, à dignidade, ao respeito, à liberdade e à convivência familiar e comunitária, além de colocá-los a salvo de toda forma de negligência, discriminação, exploração, violência, crueldade e opressão. (BRASIL, 1988)

A redação dada pelo constituinte originário reservou atenção especial à área de educação (arts. 205 a 214) determinando sua oferta como um direito de todo 
cidadão e um dever do Estado e da família. Embora pelo pressuposto constitucional o Estado deve garantir a oferta de creches, a matrícula não é obrigatória, uma vez que a obrigatoriedade do ensino se dá a partir da pré-escola, aos 4 (quatro) anos de idade (art. 208, I, CF/1988).

Para Cesiara et al (apud MORGAN et al., 2014) a Constituição Federal de 1988 foi pioneira na valorização e reconhecimento da infância. Porém, cabe destacar que essa conquista garantida pelo texto constitucional é resultado de forte mobilização social, ao qual encontra-se o movimento dos pioneiros da educação, como afirma Cury (1998 apud CORRÊA, 2007, p. 18-19):

Esta Constituição incorporou a si algo que estava presente no movimento da sociedade e que advinha do esclarecimento e da importância que já se atribuía à educação infantil. Caso isto não estivesse amadurecido entre lideranças e educadores preocupados com a educação infantil, no âmbito dos Estados membros da federação, provavelmente não seria traduzido na Constituição de 88.

Cabe destacar também a importância do art. 227 da Constituição Federal de 1988 para a conformação do Estatuto da Criança e do Adolescente, outro dispositivo fundamental para valorização do desenvolvimento integral da criança, conforme aponta Veronese (apud REIS; CUSTÓDIO, 2017).

A gama de direitos elencados basicamente no art. 227 da Constituição Federal (BRASIL, 1988), os quais constituem direitos fundamentais, de extrema relevância, não só pelo seu conteúdo como pela sua titularidade, devem obrigatoriamente, ser garantidos pelo Estatuto, e uma forma de tornar concreta essa garantia deu-se, justamente, por meio do Estatuto da Criança e do Adolescente (BRASIL, 2019), o qual tem a nobre tarefa de materializar o preceito constitucional.

A Lei $n^{\circ} 8.069$ de 13 de julho de 1990 (BRASIL, 2019) dispõe sobre o Estatuto da Criança e Adolescente:

Art. $4^{0}$ É dever da família, da comunidade, da sociedade em geral e do poder público assegurar, com absoluta prioridade, a efetivação dos direitos referentes à vida, à saúde, à alimentação, à educação, ao esporte, ao lazer, à profissionalização, à cultura, à dignidade, ao respeito, à liberdade e à convivência familiar e comunitária. 
Art. 53. A criança e o adolescente têm direito à educação, visando ao pleno desenvolvimento de sua pessoa, preparo para o exercício da cidadania e qualificação para o trabalho

$[\ldots]$.

Art. 54. É dever do Estado assegurar à criança e ao adolescente:

$[\ldots]$

IV - atendimento em creche e pré-escola às crianças de zero a seis anos de idade.

Portanto está amparada no art. $4^{\circ}$ do Estatuto da Criança e do Adolescente, uma atenção especializada que se estabelece uma particularização, ou seja, tal proteção destina-se, tão somente, às crianças e aos adolescentes, sem exceção alguma. Assim, a proteção é estendida a todos, sem distinção. Com isso, os dispositivos estatutários inauguram uma perspectiva emancipatória do direito da criança e do adolescente (REIS; CUSTÓDIO, 2017).

No mesmo sentido de aprimoramento e proteção integral à criança e ao adolescente na perspectiva da Educação Infantil, A Lei de Diretrizes e Bases da Educação Nacional (LDB nº 9.394/96) (BRASIL.MEC, 1996), posiciona a criança em seu lugar de direito na sociedade e estabelece a ela não apenas o caráter assistencialista, como também o direito a uma educação de qualidade. Essa legislação introduziu uma série de inovações em relação à Educação Básica, conforme discorre (MARQUES; PEGORARO; SILVA, 2019, p. 267):

Dentre elas a integração das creches nos sistemas de ensino, compondo, junto com as pré-escolas, a primeira etapa da Educação Básica. Também foi reafirmado o atendimento gratuito em creches e pré-escolas, garantido na Constituição Federal [...] impulsiona a autonomia das escolas no que tange à flexibilidade na organização do currículo e a pluralidade de métodos pedagógicos, desde que assegurem o desenvolvimento integral da criança até aos seis anos de idade, em seus aspectos físico, psicológico, intelectual e social, complementando a ação da família e da comunidade.

Marques, Pegoraro e Silva (2019) apontam que a primeira modificação importante da LDB foi na Lei 11.274/2006 que estendeu o ensino fundamental de oito para nove anos, com matrícula no primeiro ano (antiga primeira série) aos seis anos de idade. Conforme observou-se na redação dada pela Lei n 12.796 , de 2013: 
Art. 29. A educação infantil, primeira etapa da educação básica, tem como finalidade o desenvolvimento integral da criança de até 5 (cinco) anos, em seus aspectos físico, psicológico, intelectual e social, complementando a ação da família e da comunidade. (BRASIL, 2013)

Nesta perspectiva, a educação infantil é subdividida em duas fases: o atendimento de crianças de 0 a 3 anos, seria por meio de creches ou instituições equivalentes, já as crianças de 4 a 5 anos seriam responsabilidade da pré-escola. Diante disso, ampliou-se a preocupação em atender o público infantil de acordo com seus direitos estabelecidos por lei (COSTA, OLIVEIRA, 2011; GOMES, COSTA FILHO, 2013; LDB, 1996 apud MORGAN et al., 2014).

No âmbito da educação infantil, o Brasil possui um grande desafio a enfrentar. Trata-se da Meta no 1 do vigente Plano Nacional de Educação (PNE), Lei no 13.005, de 25 de junho de 2014 (BRASIL, 2019), que está reproduzido a seguir:

Meta 1: universalizar, até 2016, a educação infantil na préescola para as crianças de 4 (quatro) a 5 (cinco) anos de idade e ampliar a oferta de educação infantil em creches de forma a atender, no mínimo, 50\% (cinquenta por cento) das crianças de até 3 (três) anos até o final da vigência deste PNE.

Conforme relatório de 2019 referente à análise da execução dos artigos, metas e estratégias da Lei 13.005/2014, elaborado pela Campanha Nacional pelo Direito à Educação (2019), entre os destaques do relatório está a estagnação das metas 1 , referente à universalização do acesso à educação básica. O lento avanço dos indicadores evidencia que, todos os anos, milhares de crianças continuam fora da creche, da pré-escola e do ensino fundamental.

Por fim, mais recentemente a promoção do desenvolvimento integral saudável para a criança viver bem no presente e alcance seu potencial pleno no futuro, ganhou mais um importante aliado, o Marco Legal da Primeira Infância - Lei $\mathrm{N}^{\mathrm{o}}$ 13.257, de 8 de março de 2016 (BRASIL, 2019), sancionada no dia 8 de março de 2016:

Art. $1^{\circ}$ Esta Lei estabelece princípios e diretrizes para a formulação e a implementação de políticas públicas para a primeira infância em atenção à especificidade e à relevância dos primeiros anos de vida no desenvolvimento infantil e no desenvolvimento do ser humano, em consonância com os princípios e diretrizes da Lei ${ }^{\circ}$ 8.069, de 13 de julho de 1990 (Estatuto da Criança e do Adolescente); altera a Lei $n^{\circ}$ 8.069, 
de 13 de julho de 1990 (Estatuto da Criança e do Adolescente); altera os arts. $6^{\circ}, 185,304$ e 318 do Decreto-Lei $\mathrm{n}^{\circ}$ 3.689, de 3 de outubro de 1941 (Código de Processo Penal); acrescenta incisos ao art. 473 da Consolidação das Leis do Trabalho (CLT), aprovada pelo Decreto-Lei $n^{\circ} 5.452$, de $1^{\circ}$ de maio de 1943; altera os arts. $1^{\circ}, 3^{\circ}, 4^{\circ}$ e $5^{\circ}$ da Lei ${ }^{\circ} 11.770$, de 9 de setembro de 2008; e acrescenta parágrafos ao art. $5^{\circ}$ da Lei $\mathrm{n}^{\circ}$ 12.662, de 5 de junho de 2012.

Portanto, conforme o estabelecido no marco legal da primeira infância o direito de brincar, de ser cuidado por profissionais qualificados em primeira infância, devem ser prioridade nas políticas públicas. Também, o direito a ter a mãe, pai e/ou cuidador em casa nos primeiros meses, com uma licença-maternidade e paternidade justa, bem como o direito a receber cuidados médicos consistentes, especialmente os que estão em condições de vulnerabilidade. Essas são algumas das linhas que tecem a lei, por meio da criação de programas, iniciativas e serviços baseados no desenvolvimento integral das crianças, desde o nascimento até os seis anos de idade, avança no conjunto da legislação e do apontamento das políticas públicas com vistas ao fortalecimento da Educação Infantil e ao desenvolvimento integral da criança. 


\section{METODOLOGIA}

Esta pesquisa foi realizada em escolas públicas e particulares que atuavam na área da educação infantil e, para obtenção de resultados mais esclarecedores, foram entregues, aos professores, gestores e pais dessas escolas, os números descritos a seguir:

DISTRIBUIÇÃO DE ESCOLAS E NÚMERO DE PARTICIPANTES

\begin{tabular}{|l|l|l|}
\hline TIPO DE ESCOLA & $\begin{array}{l}\text { TIPO } \\
\text { PARTICIPANTE }\end{array}$ & NÚMERO DE \\
PARTICIPANTES
\end{tabular}

A pesquisa desenvolveu-se em três etapas, assim organizadas: no primeiro momento foi analisada toda a legislação acerca da educação infantil dos últimos anos, de maneira que se estabelecessem parâmetros de comparação com a realidade educacional. Na segunda etapa foi realizada investigação in loco junto às escolas públicas de educação infantil do Distrito Federal, por meio de questionários semiestruturados, como forma de verificar as expectativas e as necessidades de cada escola. Na última etapa discutiram-se os dados coletados, relacionando-os à legislação pertinente e à literatura atual acerca do assunto, chegando-se aos 
resultados do trabalho. A partir daí, propôs-se alternativas compatíveis com os anseios e os interesses emergentes na tentativa de, gradativamente, qualificar a educação infantil nas instituições, bem como na formação de profissionais para a área.

Para análise e discussão dos dados foram utilizados pressupostos das abordagens qualitativas e quantitativas, tendo sido adotados os pressupostos da epistemologia qualitativa proposta por González Rey (2007, p. 5-8, grifos do autor), que a conceitua como sendo aquela que "defende o caráter construtivo interpretativo do conhecimento, o que, de fato, implica compreender o conhecimento como produção e não como apropriação linear de uma realidade que se nos apresenta". Neste sentido, efetuou-se a coleta de dados e a busca, em material bibliográfico livros e artigos -, da legislação que trata do assunto e de conhecimentos acerca das expectativas e das necessidades relacionadas à educação infantil com vistas a tecer e a criar construção teórica a respeito.

Os dados coletados foram organizados de maneira a proporcionar apresentação e compreensão de mais qualidade, visando à análise e à discussão do conteúdo. Para isto, foram definidas algumas categorias, quais sejam: a caracterização dos participantes da pesquisa; o trabalho pedagógico; as relações interpessoais; a formação para o trabalho e a realidade escolar.

Verificou-se, também, referências importantes que caracterizassem os participantes como: idade, sexo, escolaridade e profissão que exercem. Foram analisados também os dados do ponto de vista filosófico, pedagógico, psicológico e sociológico uma vez que se buscava compreender a educação infantil em sua totalidade e também a complexidade da criança.

O questionário, instrumento utilizado na realização desta coleta, foi elaborado com perguntas estruturadas e semiestruturadas, o que permitiu perceber a situação atual do grupo pesquisado.

Objetivou-se, na medida do possível, extrapolar a mera descrição do conteúdo do instrumento, aprofundando-se na interpretação das respostas e, assim, construir o conhecimento. 


\section{A EDUCAÇÃO INFANTIL NA VISÃO DOS PROFESSORES}

\subsection{De escola pública}

Este artigo apresenta os resultados da pesquisa acerca da percepção dos professores quanto às expectativas e às necessidades da Educação Infantil em escolas públicas do Distrito Federal. Esta pesquisa foi realizada em seis escolas públicas que atuam na área da educação infantil e, posteriormente. Considerou-se necessário para o alcance dos objetivos questionar aos pais sobre as principais atribuições do professor; sobre o papel da escola; as atitudes dos docentes; a responsabilidade dos professores junto aos alunos; a contribuição dos pais ou responsáveis em relação ao desenvolvimento global da criança; a estrutura e o funcionamento da escola; a preparação dos professores; o relacionamento escolapais e a qualidade de ensino. Concluiu-se que os professores estavam preparados para a docência e satisfeitos com a profissão escolhida. A realização do diagnóstico inicial da turma foi uma das dificuldades destacadas pelos professores, que acreditam que as relações interpessoais harmônicas entre professores, diretores, coordenadores, pais e alunos determinam a qualidade do trabalho pedagógico. Espera-se, com este trabalho, contribuir para que haja mais reflexão acerca do ensino na Educação Infantil.

\subsubsection{Situando o Assunto}

A finalidade desta pesquisa foi apresentar as necessidades e as expectativas dos professores da escola pública de educação infantil e a formação do professor que pretende atuar nesse nível de ensino.

A educação infantil é aquela que atende, pedagogicamente, o período de vida escolar de crianças com idade entre 0 e 5 anos, isto com a implantação do ensino fundamental de nove anos. Entretanto, este trabalho enfatiza a faixa etária entre 3 e 5 anos.

De acordo com a Lei de Diretrizes e Bases da Educação Nacional - LDB n ${ }^{\circ}$ 9.394/96 (BRASIL.MEC, 1996), a instituição educacional que atende crianças de 0 a 
3 anos é denominada creche, e a que atende crianças de 4 e 5 anos denomina-se infantil.

A Constituição Federal da República de 1988 (BRASIL, 1988) determinou, em seu art. 208, inciso IV, que a educação às crianças até 5 (cinco) anos de idade é dever do Estado e que essa responsabilidade caberia ao antigo Curso Normal (nível técnico) ou simplesmente Magistério de segundo grau.

Na LDB 9394/96 (BRASIL.MEC, 1996), ficou determinado que todos os professores que atuassem na Educação Infantil deveriam ser graduados, pretendendo-se, com isso, garantir formação pedagógica mais qualificada e extensiva a esse nível de ensino, visto que é um período muito importante para o desenvolvimento e a aprendizagem. Nessa fase, deverão ser desenvolvidas, nas crianças, todas as dimensões que as constituem, isto é, cognitiva, afetiva, social, motora e a psicológica.

Desse modo, o objetivo geral deste trabalho foi investigar, junto aos professores, as expectativas e as necessidades da Educação Infantil, verificando-se, também, a preparação destes profissionais para atuarem nesse nível de ensino. Os objetivos específicos pretenderam:

investigar junto aos professores as expectativas e as necessidades que emergem com relação à Educação Infantil;

investigar os procedimentos didático-metodológicos utilizados pelos professores e os resultados pedagógicos até então alcançados;

verificar a opinião dos professores quanto à preparação dos profissionais que atuam na educação infantil;

propor alternativas para aperfeiçoar o processo de formação do profissional da Educação Infantil, tendo em vista as expectativas da comunidade escolar do Distrito Federal.

\subsubsection{Análise e Discussão dos Dados: principais resultados}

\subsubsection{Caracterização das participantes da pesquisa na escola pública}


Todas as participantes que assinalaram o sexo no questionário são professoras, sendo que apenas um (a) não assinalou o sexo. Conforme Morettini (2000, p. 44), com relação às mulheres assumirem a educação, ela afirma:

Nessa perspectiva, ser professora na área de Educação Infantil é uma ideia que não atrai as famílias das frações mais altas da classe média, ficando a profissão reservada para os setores mais baixos da classe, para quem esta área de atuação ainda pode significar opção de vida e, nesses setores, às mulheres.

Em relação à faixa etária dos docentes, nenhuma tinha menos de vinte anos; cinco professoras estavam entre as faixas de 20 e 30 anos, quatorze estavam entre 31 e 40 anos, nove estavam entre 41 e 50 anos e duas já tinham entre 51 e 60 anos.

Apenas três professoras afirmaram ser muito valorizadas pelo trabalho realizado na Educação Infantil. Vinte e oito participantes salientaram estar satisfeitas com a profissão, mesmo conhecendo as dificuldades inerentes ao magistério. Com relação à profissão de professora dessa modalidade de ensino, nove regentes disseram acreditar ser função muito estressante. Nesse sentido, dezenove participantes afirmaram que o trabalho pedagógico na Educação Infantil é excessivamente mais exigente que nas demais modalidades de ensino, portanto, deveria ser mais bem remunerado. Nesse sentido, Morettini (2000,p. 24, grifos do autor):

[...] a respeitabilidade que envolve a profissão de professor deve-se ao aspecto não manual de sua atividade, que desde a primeira divisão social do trabalho, quando a atividade intelectual se separou do trabalho pesado, tido como degradante e indigno.

O professor aceita essa dignidade que envolve o seu trabalho, em troca de uma recompensa que não é material - o professor trabalha para "o bem". Nesse sentido, reside também na finalidade da tarefa, a especificidade de seu trabalho.

Mesmo conhecendo todas as dificuldades inerentes ao magistério, a maioria das participantes está satisfeita com a profissão que escolheu e apenas uma dentre as regentes afirmou que deixará a Educação Infantil quando conseguir outro emprego.

\subsubsection{Trabalho Pedagógico}

De acordo com a opinião das participantes existem alguns atributos que o professor de educação infantil deve ter e a formação específica para atuar nessa 
modalidade foi o ponto mais citado. Para a maioria dos participantes, o profissional que atua na Educação Infantil deve sempre buscar capacitação. Nesse sentido, Morettini (2000, p. 45, grifos do autor) afirma que:

Expressões como a escola é a extensão do lar; a professora é a segunda mãe ou a tia; a professora é a jardineira a criança é a sementinha (herança dos jardins de i) sempre povoam o universo da Educação Infantil, impregnando-a de preconceitos e estabelecendo nessa área (mais que nas outras) a predominância do emocional, do pessoal, da afetividade sobre o profissional, na concepção de educação dessa professora-mulher.

Gostar de crianças, ter paciência, ser sensível, foram outras características apresentadas como atributos que deve ter esse profissional.

Na opinião dos professores existem algumas dificuldades ao assumir uma nova turma de educação infantil e a maioria concordou que a realização do diagnóstico inicial seja o ponto mais difícil. Conhecer e perceber as particularidades de cada criança apareceu como segunda dificuldade que um professor enfrenta na sala de aula. Em terceiro lugar citaram a falta de limites das crianças.

Quando avaliaram a qualidade do trabalho que os demais professores desenvolvem com as crianças na escola, todas as entrevistadas responderam que o trabalho é muito bom. Um participante afirmou que a qualidade do trabalho "é muito boa, diria até excelente. Todos trabalham coletivamente para o crescimento do aluno".

Na opinião de sete participantes a escola integral é pedagogicamente benéfica ao desenvolvimento global do aluno. Os demais discordam. Três professoras afirmaram que a escola de horário integral é interessante para as famílias de menor poder aquisitivo.

A maior parte das professoras afirmou que participam da elaboração do Planejamento Pedagógico da escola onde trabalham. Cinco docentes, no entanto, responderam que não participaram da elaboração deste documento. Para Libâneo (2013a, p. 96), em relação a esse aspecto:

A metodologia do trabalho docente inclui, pelo menos, os seguintes elementos: os movimentos (ou passos) do processo de ensino no decorrer de uma aula ou unidade didática; 
métodos, formas e procedimentos de docência e aprendizagem; os materiais didáticos e as técnicas de ensino; a organização da situação de ensino.

Outro aspecto analisado foram as atividades relacionadas às datas comemorativas. Onze profissionais responderam que todas as atividades relacionadas às comemorações que envolvem decoração das instalações da escola devem ser realizadas pelas crianças, sob a supervisão dos professores. Três, dentre todas as professoras, afirmaram que parte das atividades deve ser feita pelos professores. Nesse sentido, todas as docentes concordaram não ser perda de tempo ou exploração deles como profissionais, trabalhar na decoração da sala de aula e da escola, nas festividades.

Para as entrevistadas, as escolas onde atuam não adotaram a pedagogia tradicional, dando, assim, mais liberdade à criatividade do professor. Conforme leciona González Rey (grifo do autor, apud MARTINEZ; TACCA, 2010, p. 133), ao se referir à teoria de Vygotsky, “o aprender pode, desse ponto de vista, passar a ser compreendido como produção e não como reprodução, o que representaria uma mudança radical nas formas em que a aprendizagem está institucionalizada hoje [...]". Afirma ainda este autor que "a aprendizagem não é uma reprodução objetiva de conteúdos, 'dados', é uma produção subjetiva que tem a marca do sujeito que aprende."

Para vinte e seis participantes, o trabalho pedagógico com crianças exige muito equilíbrio emocional por parte do professor; e para cinco desses profissionais, não há apoio da coordenação escolar nesse sentido.

Doze professores disseram acreditar que a prática docente desenvolvida na escola seja suficiente para a formação dos alunos. Vinte e dois participantes opinaram que se tivessem assistência pedagógica na escola para atender aos alunos, o trabalho em sala de aula fluiria de forma mais eficiente.

Em relação aos gestores escolares, dez professoras afirmaram que eles não facilitam o trabalho docente, sendo que seis profissionais salientaram que a coordenação pedagógica não se preocupa em acompanhar os professores, desempenhando esse trabalho de forma burocrática. Para Libâneo, Oliveira e Toschi (2012, p. 339), a gestão democrática "não pode ficar restrita ao discurso da 
participação e suas formas externas - as eleições, as assembleias e as reuniões. Ao contrário, ela deve estar a serviço dos objetivos do ensino, especialmente da qualidade cognitiva dos processos de ensino aprendizagem". Apenas sete participantes afirmaram que as escolas onde atuam dispõem de apoio de outros profissionais como, por exemplo, nutricionista e psicólogo.

Quanto à supervisão das tarefas escolares pelos pais, apenas um participante afirmou que este acompanhamento atrapalha as atividades de sala de aula. Vinte e cinco entrevistados disseram que onde trabalham são motivados a desenvolver projetos pedagógicos, com autonomia para a escolha dos temas. Cinco participantes afirmaram que não são motivadas. Dezesseis professores afirmaram que os pais estão sempre presentes nas reuniões escolares. Seis participantes registraram que o professor da escola integral é menos produtivo devido ao desgaste físico e mental.

No trabalho pedagógico foram observados os projetos desenvolvidos e aplicados à Educação Infantil. Vinte e oito professores disseram desenvolver estes projetos na rotina da sala de aula, e dois regentes não responderam essa pergunta. As professoras que trabalham com projetos citaram alguns: Hora do Conto; Projeto Boneca Contadora de Histórias; Valorizando as Diferenças; Cidadania não tem idade; Projeto Alimentação Saudável.

\subsubsection{Realidade Escolar}

Em relação à idade das crianças sob a responsabilidade do professor, vinte e seis entrevistados não responderam a esta pergunta e três professores responderam ser responsáveis por crianças entre quatro e cinco anos. Um docente registrou que leciona em escola que tem Educação Infantil e Ensino Fundamental, na qual ele atende a crianças entre quatro e quatorze anos.

Quando questionados a respeito da estrutura e dos recursos didáticos presentes na escola necessários ao desenvolvimento e à aprendizagem dos alunos, grande parte das professoras afirmou que a escola os tem e os utiliza adequadamente. Apenas três participantes afirmaram que a instituição não trabalha com este suporte, pois não os tem de forma adequada, e que tudo o que existe na escola é muito precário; um docente desabafou dizendo que, "muitos recursos adquiro com meu próprio salário, como, por exemplo, jogos”. 
Quanto aos recursos didáticos disponíveis, seis professoras disseram acreditar não serem suficientes para desenvolver as competências e habilidades previstas no planejamento pedagógico. Os demais afirmaram que a escola tem recursos suficientes.

Vinte e três participantes afirmaram que a escola onde atuam promove a formação continuada de seus professores, sendo que sete, da mesma escola, negaram esta afirmação. Em referência à formação continuada Morettini (2000, p.12), afirma que:

[...] no desempenho diário da profissão, a professora préescolar vai adquirindo conhecimentos, concepções elaboradas nos diferentes espaços de aprendizagem, em cursos de preparação para o Magistério ou na formação em serviço, em leituras e discussões em grupo, nas vivências do ensino, nas relações com os colegas e com os alunos, enfim, nas tantas relações sociais estabelecidas.

Quatorze docentes sustentaram que são incentivadas à busca por informações e a atuarem com independência.

Para dezesseis participantes a escola onde atuam não interage com órgãos ligados aos direitos da criança e quatorze responderam que na instituição de ensino na qual trabalham existe essa vinculação. Vinte e dois participantes deixaram claro que os pais devem acompanhar diariamente as tarefas dos filhos e vinte e dois entrevistados entendem que estão preparados para receber sugestões dos pais em relação às práticas pedagógicas aplicadas.

\subsubsection{Relações Interpessoais}

No ambiente escolar, as relações interpessoais acontecem em vários contextos. Tem-se a relação professor-aluno; aluno-aluno; professores- responsáveis; professor-coordenação da escola. Dependendo da postura da instituição escolar, os conflitos decorrentes destas relações podem ser trabalhados positivamente, havendo ou não crescimento de todos os envolvidos, gerando desconforto e insegurança para as famílias e os profissionais da escola. Morettini (2000, p. 22), escreve que "rever a atividade docente significa rever o professor em suas relações sociais, tanto na especificidade da tarefa que ele realiza como nas manifestações reveladas pelo grupo ao qual pertence e pela sociedade como um todo." 
No ambiente de sala de aula de Educação Infantil as professoras apresentaram as principais dificuldades de relacionamento, sendo a falta de limites das crianças o ponto mais citado entre as participantes que entendem ser esta a maior dificuldade da relação professor-aluno. A agressividade e a adaptação também foram citadas, mas para uma docente não há problemas na relação professor-aluno, pois as crianças são dóceis e a têm como exemplo.

Na relação aluno-aluno grande parte das participantes concordou que o egocentrismo é a maior dificuldade do inter-relacionamento entre as crianças. A socialização dos alunos foi outro ponto citado.

Na relação professores-responsáveis, doze participantes atestam que a maior dificuldade está na falta de participação, de cooperação e de parceria da família com a escola. Uma professora observa que a minoria dos pais participa da vida escolar do filho. Outro aspecto levantado pelas docentes é o equívoco de algumas famílias ao considerar a professora como babá, não valorizando o trabalho que é desenvolvido em sala de aula. Para um dos professores, os pais confundem muito o trabalho das docentes com o trabalho de "cuidadores". Para esses participantes, as famílias têm percepção limitada do trabalho realizado na educação infantil. Em relação a isso Morettini (2000, p. 45, grifo do autor) afirma que “[...] o sentido da afetividade passou a ser visto de uma maneira inadequada, fator que ajudou na caracterização da professora de crianças pequenas como apenas 'mãe', numa postura que o aspecto afetivo aparece dissociado do cognitivo e pela qual ela não precisaria ser competente.”

Quatro docentes veem a participação dos pais ou da família como não colaboradora no sucesso do processo ensino-aprendizagem. Os demais creem que essa participação é sim importante. Todas as professoras afirmaram que os pais têm formação para interferir no trabalho da escola.

Enquanto três participantes salientaram que os pais não devam colaborar na parte de eventos e conservação da escola; oito participantes afirmaram que os pais não devem participar diretamente, mas precisam intervir, quando necessário, no projeto político-pedagógico da escola. 
Na relação entre professor e coordenação, dez professoras afirmaram que não existem dificuldades de relacionamento, e uma docente citou sua experiência, mostrando que na escola onde atua sempre há diálogo e, que, por isso, não existem dificuldades. Para seis participantes a falta de apoio é a maior dificuldade entre docentes e coordenação.

Outro ponto analisado nessa categoria, no qual as participantes deveriam afirmar sim ou não, é se a escola em que atuam promove o relacionamento harmonioso entre os profissionais, melhorando o processo de ensino e aprendizagem. Vinte e sete docentes afirmaram que sim, que a escola promove este relacionamento harmonioso e três professoras afirmaram que não.

A maioria das participantes disse acreditar que as relações interpessoais na escola determinam a qualidade do trabalho pedagógico, e que, por isso, professores, diretoras e coordenadores devem primar pelo convívio harmônico, minimizando a competição. Apenas três regentes discordam desta afirmação. Segundo Morettini (2000, p. 23):

[...] as professoras constituem-se no transcurso de suas trajetórias, através da apropriação da cultura historicamente acumulada, processo que acontece em gradual interiorização do externo, do social e a sua transformação em interno, individual. Esse processo produz-se na comunicação e nas relações sociais que as professoras estabelecem nos diferentes grupos que participam, na atividade que realizam, de acordo com as suas condições objetivas de vida.

Uma professora assegura que não existe troca de experiências na escola onde trabalha, enquanto para os demais participantes na instituição onde atuam há troca de ideias e de experiências para enriquecer o trabalho pedagógico da escola.

Quando questionadas acerca do posicionamento que a escola deve ter em referência ao relacionamento harmonioso entre profissionais, família e alunos, três participantes sustentam não haver este posicionamento na escola onde trabalham.

\subsubsection{Formação para o trabalho}

Após análise dos questionários constatou-se que duas docentes concluíram apenas o curso magistério, dez concluíram a graduação e dezoito realizaram a pósgraduação. 
Em relação ao tempo decorrido desde a conclusão do último curso, técnico ou superior, tem-se os seguintes dados: onze participantes já terminaram há cinco anos; doze tinham se formado entre seis e quinze anos e duas tinha mais de dezesseis anos, desde a última formação. Cinco participantes não responderam a esta pergunta.

Em relação ao tempo de experiência dos professores na Educação Infantil, verificou-se que doze regentes tinham até cinco anos de experiência, doze entre seis e quinze anos e cinco participantes mais de dezesseis anos de experiência. Uma participante não respondeu a esta pergunta. As participantes foram questionadas acerca dos cursos realizados na área de Educação infantil e todas elas afirmaram que fizeram pelo menos um curso.

Durante o curso de graduação, quatorze entrevistados afirmaram que não foram preparadas adequadamente para atuar nessa modalidade de ensino. As demais participantes afirmaram que havia preocupação por parte das instituições formadoras em prepará-las para lidarem com os problemas do dia a dia da educação infantil. Saviani (2009, p. 154) aponta que,

com um quadro de professores altamente qualificado e fortemente motivado trabalhando em tempo integral numa única escola, estaremos formando os tão decantados cidadãos conscientes, críticos, criativos, esclarecidos e tecnicamente competentes para ocupar os postos do fervilhante mercado de trabalho de um país que viria a recuperar, a pleno vapor, sua capacidade produtiva. Estaria criando, por esse caminho, o tão desejado círculo virtuoso do desenvolvimento.

Quando questionadas a respeito da relação entre o que é ensinado no curso de Pedagogia e a realidade encontrada nas escolas, as opiniões das professoras ficaram divididas. Quinze afirmaram que existe longa distância entre a teoria ensinada nas graduações e a prática vivenciada em sala de aula. As demais participantes afirmaram que o curso de Pedagogia forneceu as bases necessárias para a prática em sala de aula.

Outro ponto de análise foi a necessidade que os professores sentem de melhor formação para desenvolverem um bom trabalho pedagógico na escola em que atuam. Doze profissionais afirmaram estar nessa situação, dezoito docentes encontravam-se satisfeitas com sua preparação e vinte e uma participantes declararam que sempre participam de cursos voltados para a Educação Infantil. Seis docentes concordam 
que as teorias ou tendências pedagógicas estudadas durante a graduação nada têm a ver com a realidade escolar. Segundo Pinto (2005, p. 50),

Evidencia-se, nesse contexto, a necessidade de se dedicar atenção especial à orientação dos professores, por meio de cursos de formação que priorizem a relação teoria-prática, num espaço de construção coletiva de conhecimento possibilitando o desenvolvimento de competências necessárias a sua atuação profissional, com vistas a favorecer 0 desenvolvimento integral do educando e o sucesso do processo de ensino-aprendizagem.

Dezessete professores disseram acreditar ser o mais indicado para os profissionais que atuarão na Educação Infantil.

\subsubsection{Considerações Finais}

Pode-se perceber, por este trabalho, que no que tange à formação acadêmica dos docentes das escolas públicas constatou-se que dois deles concluíram apenas o curso magistério, dez concluíram a graduação e dezoito participantes concluíram a pós-graduação, o que possibilita a conclusão de que os professores da escola pública de Educação Infantil estão preparados para a docência. Todas as participantes fizeram pelo menos um curso na área de educação infantil e seis afirmaram que as teorias ou tendências pedagógicas estudadas durante a graduação nada tinham a ver com a realidade escolar em que atuam. Dezoito docentes encontravam-se satisfeitas com a preparação que tinham recebido para o magistério e vinte e uma entrevistadas declararam que sempre participam de cursos voltados para a Educação Infantil.

Em relação ao tempo de experiência das participantes, verificou-se que a maioria se encontrava com mais de quatro anos na regência desta modalidade de ensino. O trabalho pedagógico com crianças, segundo vinte e seis participantes, exige muito equilíbrio emocional por parte do professor.

Foi importante perceber que, apesar de todas as dificuldades inerentes ao magistério que os professores vivenciam, a maioria dos participantes está satisfeita com a profissão que escolheu e apenas uma regente afirmou que deixará a Educação Infantil quando conseguir outro emprego. Entretanto, dezenove participantes afirmaram que o trabalho pedagógico na Educação Infantil é excessivamente mais 
exigente que nos demais níveis de ensino, e que deveria, portanto, ser mais bem remunerado.

As principais características e atributos de um professor de educação infantil destacados pelos participantes foram: gostar de crianças, ter paciência, ser sensível e ter formação adequada para a atuação. Com relação ao trabalho pedagógico, vinte e oito professoras afirmaram desenvolver projetos pedagógicos na rotina da sala de aula.

Os participantes consideraram ser fundamental a participação da família na elaboração e na intervenção do projeto político-pedagógico da escola, mas não contam sistematicamente com a presença delas nas reuniões escolares. Vinte e seis entrevistados afirmaram que os pais recebem indicativos da importância da sua participação na escola. Quanto à participação dos pais, quatro docentes disseram acreditar que a participação da família não colabora para o sucesso do processo ensino-aprendizagem. Os demais creem que a participação dos pais seja importante. Todos os professores afirmaram que os pais têm formação para interferir no trabalho da escola.

Quanto à estrutura e funcionamento da escola, três participantes afirmaram que a instituição onde atuam não oferece condições necessárias ao desenvolvimento do trabalho pedagógico, mas os demais salientaram que na instituição onde atuam existem condições necessárias ao trabalho. Dezesseis participantes afirmaram que a escola onde atuam não tem vínculos com órgãos ligados aos direitos da criança e quatorze afirmaram que ela tem sim, esta vinculação.

Pelos dados apresentados percebeu-se que não há dificuldades de relacionamento entre professores e coordenadores e vinte e sete docentes afirmaram que a escola promove o relacionamento harmonioso entre os profissionais. A maioria dos participantes afirmou acreditar que as relações interpessoais na escola determinam a qualidade do trabalho pedagógico e, por isso, professores, diretores e coordenadores devem primar pelo convívio harmônico, minimizando a competição.

Considerou-se que pelo número de professores que participaram da pesquisa pode-se estabelecer percepção indicativa da situação da educação infantil no Distrito Federal. Esta pesquisa faz parte de uma pesquisa maior que abrange também a 
participação de gestores, pais, tanto de escolas públicas quanto das escolas particulares, e professores de escolas particulares. Todos esses dados, reunidos, aprofundaram os resultados da pesquisa, uma vez que se pretende, ao final, obter resultados contributivos para melhoria do processo de formação do educador no Distrito Federal e a divulgação dos resultados em eventos e em periódicos científicos, em nível regional, nacional e internacional.

\subsection{De escola particular}

Este artigo apresenta os resultados da pesquisa a respeito da percepção dos professores quanto às expectativas e às necessidades da Educação Infantil em escolas particulares do Distrito Federal. Foi utilizado o método qualitativo e, como instrumento, o questionário. Concluiu-se que os professores se encontravam preparados para a docência e satisfeitos com a profissão escolhida. A adaptação da criança à escola foi uma das dificuldades destacadas pelos professores, que acreditam que as relações interpessoais harmônicas entre professores, diretores, coordenadores, pais e alunos determinam a qualidade do trabalho pedagógico. Espera-se, com este trabalho, contribuir para que haja mais reflexão acerca do ensino na Educação Infantil.

\subsubsection{Situando o Assunto}

Este trabalho apresenta as necessidades e as expectativas dos professores de educação infantil da rede de ensino particular e a formação do professor que pretende atuar neste nível de ensino. Pretendeu também investigar, diante das mudanças governamentais realizadas nos últimos dez anos, se o profissional que atua na Educação Infantil se encontra preparado frente a esta realidade no Distrito Federal.

Compreende-se como Educação Infantil, aquela que atende pedagogicamente o período de vida escolar de crianças com idade entre 0 e 5 anos, isto com a implantação do Ensino Fundamental de nove anos. Este trabalho, no entanto, enfatiza a faixa etária compreendida entre 3 e 5 anos. 
De acordo com a Lei de Diretrizes e Bases da Educação Nacional - LDB n ${ }^{\circ}$ 9.394/96 (BRASIL.MEC, 1996), a instituição educacional que atende crianças de 0 a 3 anos é denominada creche, e a que atende crianças de 4 e 5 anos denomina-se infantil.

A Constituição Federal da República de 1988 (BRASIL, 1988) determinou, em seu art. 208, inciso IV, que a educação na faixa etária de 4 e 5 anos é dever do Estado e que essa responsabilidade caberia ao antigo Curso Normal (nível técnico), ou simplesmente, Magistério de segundo grau.

Com as alterações oriundas da LDB 9394/96 (BRASIL.MEC, 1996), o Magistério, de nível técnico, foi suprimido, ficando determinado que todos os professores que atuassem na Educação Infantil deveriam ser graduados.

Desse modo, o objetivo geral deste trabalho foi investigar, junto aos professores, as expectativas e as necessidades da Educação Infantil, verificando-se também a preparação desses profissionais para atuarem nesse nível de ensino. Assim, os objetivos específicos deste trabalho pretenderam:

Investigar, junto aos professores, as expectativas e as necessidades que emergem em relação à Educação Infantil.

Investigar os procedimentos didático-metodológicos utilizados pelos professores e os resultados pedagógicos até então alcançados.

Verificar a opinião dos professores quanto à preparação dos profissionais que atuam na Educação Infantil.

Propor alternativas para aperfeiçoar o processo de formação do profissional da Educação Infantil, tendo em vista as expectativas da comunidade escolar do Distrito Federal.

\subsubsection{Análise e discussão dos dados: principais resultados}

\subsubsection{Caracterização dos participantes da pesquisa na escola particular}

Quanto à faixa etária das participantes da pesquisa, uma professora tinha menos de vinte anos de idade; quinze encontravam-se entre 20 e 30 anos de idade, 
portanto, faixa etária predominante; treze professoras estavam na faixa etária entre 31 e 40; oito estavam entre 41 e 50 anos de idade; uma entre 51 a 60 anos de idade e seis não responderam à pergunta.

No que tange à formação acadêmica das docentes das escolas particulares, dez fizeram apenas o Magistério, dezessete concluíram a Graduação. Onze professoras fizeram Pós-graduação, e seis entrevistadas não responderam a esta pergunta.

Em relação ao tempo decorrido desde a conclusão do último curso realizado técnico ou superior -, foram obtidos os seguintes dados: vinte e três participantes já estavam com até quatro anos de formadas na graduação; nove docentes tinham até nove anos desde a conclusão do último curso; três professoras tinham até quinze anos de formação; três entrevistadas tinham mais de vinte anos; duas professoras estavam cursando a graduação e apenas quatro docentes não responderam.

Quanto ao tempo de experiência das participantes na Educação Infantil, verificou-se que dezenove docentes tinham até três anos na regência desta modalidade de ensino; onze professoras já tinham entre quatro e seis anos de experiência atuando na Educação Infantil; oito docentes estavam, no mínimo, há sete anos e no máximo há dez anos nesta experiência; e seis professoras tinham mais de dezesseis anos de prática.

\subsubsection{O trabalho pedagógico}

Em relação ao trabalho pedagógico desenvolvido, foram observados os projetos aplicados na Educação Infantil, e quinze professoras relataram desenvolver projetos em sua rotina da sala de aula, contudo, as demais regentes não responderam a esta pergunta. As professoras que trabalhavam com projetos destacaram: Projeto Criança - CNPq; Roda de Leitura; Projeto da Saúde; Projeto de Horta; Projeto de Meio Ambiente; Projeto Folclore; Projeto Autoestima; Projeto Semana da Alimentação e de Incentivo à Leitura.

Na opinião das participantes, dentre os atributos que um professor de Educação Infantil deve ter, ficou evidenciado que amor, carinho e paciência estão em primeiro lugar e, em segundo, a formação adequada para a atuação nessa 
modalidade de ensino e o conhecimento da faixa etária das crianças. Outros atributos citados foram: compromisso, determinação, flexibilidade, dinamismo, mediação de conhecimentos, respeito às diferenças, gosto pela profissão e por crianças. Dentre as participantes, dez não responderam à pergunta. Segundo Libâneo (2013a, p. 28), “[...] é verdade que muitos professores manifestam especial tendência e gosto pela profissão, assim como se sabe que mais tempo de experiência ajuda no desempenho profissional”. Entretanto, conforme escreve o autor: “[...] domínio das bases teóricocientíficas e técnicas, e sua articulação com as exigências concretas do ensino, permitem maior segurança profissional, de modo que o docente ganhe base para pensar sua prática e aprimore sempre mais a qualidade do seu trabalho".

Perguntadas se existem algumas dificuldades ao assumir uma nova turma de Educação Infantil, a maioria das professoras concordou que a adaptação das crianças ao novo ambiente e à nova professora, no início do ano, é o momento mais difícil. Em seguida, vem a insegurança e a falta de confiança das famílias em relação ao trabalho do professor, o que dificulta a realização do trabalho pedagógico. Conhecer e perceber as particularidades de cada criança aparece como a terceira dificuldade. Somente uma participante afirmou não ter nenhuma dificuldade ao receber uma nova turma.

Quanto à avaliação que fariam a respeito da qualidade do trabalho das demais professoras, as respostas foram variadas: uma participante respondeu que o trabalho pedagógico era péssimo, mas todas as demais responderam que o trabalho pedagógico desenvolvido pelas professoras da escola em que atuam era ótimo ou excelente; uma professora informou que a cada dia aprende com os colegas atividades diferenciadas, tais como, música ou uma história, considerando que existe uma troca muito gratificante; outra participante afirmou não ter conhecimento suficiente para avaliar o trabalho das demais professoras.

Para o tópico acerca do planejamento pedagógico, grande parte das professoras descreveu que nas escolas onde trabalha, ele existe e que elas participam de sua elaboração e de sua execução. Todavia, é relevante salientar que seis docentes responderam que não participaram da elaboração desse documento. Segundo Libâneo (2013a, p. 230), o plano da escola é: 
[...] o plano pedagógico e administrativo da unidade escolar, onde se explicita a concepção pedagógica do corpo docente, as bases teórico-metodológicas da organização didática, a contextualização social, econômica, política e cultural da escola, a caracterização da clientela escolar, os objetivos educacionais gerais, a estrutura curricular, diretrizes metodológicas gerais, o sistema de avaliação do plano, a estrutura organizacional e administrativa.

Outro aspecto analisado foi em relação à execução das atividades relacionadas às datas comemorativas. Nesse ponto, o grupo ficou dividido. Onze professoras responderam que todas as atividades relacionadas às comemorações que envolvam decoração das instalações da escola devem ser realizadas pelas crianças, sob a supervisão dos professores; mas dezenove responderam que é de responsabilidade apenas do professor. Nesse sentido, uma docente afirmou ser uma "perda de tempo e exploração", dos professores terem de decorar a sala de aula e a escola, para as festividades, enquanto as demais são a favor da participação dos professores na ornamentação das salas e da escola em datas festivas.

Segundo os dados coletados, as escolas em que as docentes atuam não adotam pedagogia tradicional, proporcionando, assim, mais liberdade à criatividade.

\subsubsection{Realidade escolar}

Para caracterizar a realidade escolar vivenciada, as participantes responderam a questionamentos referentes à estrutura física da escola, à participação da família e à interação entre professores/pais/escola.

Na avaliação docente com relação à infraestrutura e aos recursos didáticos necessários à aprendizagem dos alunos, as participantes afirmaram que na escola existe esta estrutura: salas de leitura, bibliotecas, sala de artes, computadores, sala de vídeo, cozinha, auditório, parque e jogos pedagógicos, tudo compondo a realidade da maior parte das entrevistadas. Apenas uma docente enfatizou não existir tal estrutura em sua escola. Portanto, a maioria das participantes concordou que a escola em que atua oferece condições necessárias para o desenvolvimento do trabalho pedagógico e apenas três professoras discordaram da questão.

A estruturação do espaço, a forma como os materiais estão organizados, a qualidade e adequação dos mesmos são elementos essenciais de um projeto educativo. Espaço físico, materiais, brinquedos, instrumentos sonoros e mobiliários não 
devem ser vistos como elementos passivos, mas como componentes ativos do processo educacional que refletem a concepção de educação assumida pela instituição. Constituemse em poderosos auxiliares da aprendizagem (BRASIL, 1998, p. 68).

Quanto aos recursos didáticos disponíveis, doze participantes relataram que não são suficientes para desenvolver as competências e habilidades previstas no planejamento e as demais entrevistadas concordaram que os recursos oferecidos estavam de acordo com as necessidades.

No tocante à autonomia das professoras para desenvolverem projetos pedagógicos, dezoito participantes mencionaram que, na escola onde atuam, foram estimuladas a elaborar projetos de acordo com a necessidade de cada turma. As demais participantes não responderam a essa pergunta.

Elaborar e implantar um projeto educativo requer das equipes de profissionais das instituições um grande esforço conjunto. A direção da instituição tem um papel chave neste processo quando auxilia a criação de um clima democrático e pluralista (BRASIL, 1998, p. 67).

No que se refere à interação escola e órgãos ligados aos direitos da criança, notou-se que nove entrevistadas afirmaram existir esta relação.

Em relação à participação dos pais no sucesso do processo ensinoaprendizagem das crianças, a maioria das participantes concordou ser uma parceria benéfica para o desenvolvimento dos alunos, enquanto três docentes não concordaram com esta situação. Nesse ponto, cinco docentes afirmaram que os pais não têm formação adequada para interferir no trabalho da escola, e as demais salientaram que os pais têm sim formação adequada para opinar no trabalho escolar. Ressalte-se que, todas as docentes afirmaram que os pais devem acompanhar diariamente as tarefas escolares de seus filhos e quase todas opinaram sentirem-se preparadas para receber sugestões dos pais em relação à prática pedagógica desenvolvida em sala de aula.

Os professores parecem se esquecer da importância dos pais no desenvolvimento e na aprendizagem dos alunos. Nesse aspecto, Souza (2008, p. 104) tem uma contribuição importante: 
De fato, nós, pais e professores, somos para os nossos filhos como verdadeiros espelhos, onde se refletem a vida, o mundo, as formas das relações pessoais e sociais. Em geral, seus olhos nos veem como heróis, ídolos ou sábios e como detentores de todo conhecimento do mundo. Ademais, tendemos a ser, para eles a referência maior, da moral, da ética, dos valores, do poder e da verdade. A forma como nós, pais e mestres, vemos o outro e o mundo e nos comportamos diante deles, acaba por influenciar as aprendizagens e as posturas assumidas por nossos filhos ou alunos diante disso.

Quanto à assiduidade da família às reuniões escolares, dezenove participantes afirmaram que nem sempre é possível contar com a presença dela, acreditando ser fundamental a participação da família na elaboração e na intervenção do projeto político pedagógico da escola. Todos os participantes disseram que a família deve colaborar na parte de eventos e na conservação da parte física da escola, demonstrando a importância da sua participação na escola, valorizando, portanto, sua presença. Nesse sentido, pode-se confirmar que

[...] os responsáveis devem interessar-se pelo que as crianças possam ver, agir, pensar, sentir, escolher, perguntar. Se conseguirem fazer isto, estarão contribuindo nas interações positivas entre a família e a escola e possibilitando o próprio desenvolvimento da autonomia e da própria cidadania das crianças (GOMES, 2002, p. 9).

Quanto à educação integral, duas docentes responderam que professores que trabalham o dia todo são menos produtivos que os demais, devido ao desgaste físico e mental. Para dar suporte e apoio ao trabalho com a Educação Infantil, três participantes afirmaram que a escola conta com a colaboração de outros profissionais como nutricionista e psicólogo, entre outros.

\subsubsection{Relações interpessoais}

No ambiente escolar, as relações interpessoais acontecem em várias situações. Tem-se a relação professor-aluno; aluno-aluno; professores-responsáveis e professor-coordenação da escola. Dependendo da postura na forma de trabalho da instituição escolar, os conflitos decorrentes destas relações podem ser modificados positivamente, havendo crescimento de todos os envolvidos. Caso contrário, esses conflitos geram desconforto e insegurança para as famílias e profissionais da escola.

O ambiente de cooperação e respeito entre os profissionais e entre esses e as famílias favorece a busca de uma linha coerente de ação. Respeito às diferenças, explicitação de 
conflitos, cooperação, complementação, negociação e procura de soluções e acordos devem ser a base das relações entre adultos (BRASIL, 1998, p. 6).

As professoras apontaram as principais dificuldades de relacionamento na relação professor-aluno e, nesse aspecto, a adaptação da criança à classe de Educação Infantil foi o ponto mais citado, sendo esta a maior dificuldade da relação. Cinco participantes afirmaram que a maior dificuldade encontrada está relacionada à falta de limites e uma professora salientou que a falta de limites em casa dificulta a construção do estudante em sala de aula. Duas profissionais afirmaram que a falta de respeito é a maior dificuldade. Duas docentes disseram não existir dificuldades na relação professor-aluno e uma professora descreveu que as crianças são muito carinhosas e atenciosas, não existindo, por isso, dificuldades de relacionamento. Uma professora relatou que tem um aluno com dificuldade na fala e que, em alguns momentos, ela não consegue compreender o que a criança diz, dificultando, assim, seu relacionamento com essa criança. Quanto a esse aspecto, Libâneo (2013a, p. 250) afirma que "[...] o trabalho docente se caracteriza por um constante vaivém entre as tarefas cognoscitivas colocadas pelo professor e o nível de preparo para resolverem as tarefas". E afirma ainda que:

Na sala de aula o professor exerce uma autoridade, fruto de qualidades intelectuais, morais e técnicas. Ela é um atributo da condição profissional do professor e é exercida como estímulo e ajuda para o desenvolvimento independente dos alunos. O professor estabelece objetivos sociais e pedagógicos, seleciona e organiza os conteúdos, escolhe métodos, organiza a classe. Entretanto, essas ações docentes devem orientar os alunos para que respondam a elas como sujeitos ativos e independentes. A autoridade deve fecundar a relação educativa e não a cercar (LIBÂNEO, 2013a, p. 251).

Quanto à relação aluno-aluno, quatorze participantes relataram que o "egocentrismo" é a maior dificuldade de relacionamento entre as crianças, gerando vários conflitos em sala de aula, como, por exemplo, brigas na disputa por brinquedos, espaço e objetos. "O espaço na instituição de educação infantil deve propiciar condições para que as crianças possam usufruí-lo em benefício do seu desenvolvimento e aprendizagem” (BRASIL, 1998, p. 69).

Com respeito à relação professores-responsáveis, sete participantes apresentaram como maior dificuldade a falta de cooperação da família com a escola. 
Na maioria das vezes, segundo as participantes, os pais tentam descumprir as regras da escola, são ausentes nas reuniões escolares ou não conferem diariamente a agenda escolar do filho. A falta de tempo da família para acompanhar a vida escolar do filho dificulta a relação família-escola. Outro aspecto relevante levantado pelas docentes é o equívoco que algumas famílias cometem tratando a professora como "babá". Uma docente relatou que, em alguns momentos, os pais querem ensinar a professora o que deve ser trabalhado em sala de aula. Duas regentes declararam que, quando há diálogo entre a família e a escola, a confiança se fortalece, fazendo com que o trabalho em sala de aula seja prazeroso tanto para o professor quanto para o aluno.

Com referência à relação entre professor e coordenação, sete professoras apontaram que a maior dificuldade está na falta de comunicação clara e objetiva com coordenadores e a falta de diálogo aparece como o ponto mais citado neste tópico. Em segundo lugar, as participantes mencionaram o despreparo do coordenador para lidar com situações cotidianas da Educação Infantil. A falta de liberdade e a dificuldade de expor novas ideias também foram apontadas como dificuldades nessa relação. Uma docente relatou que a "[...] coordenação e o professor devem trabalhar juntos para um bom desenvolvimento e aprendizagem do aluno". De acordo com os dados coletados, percebe-se que há necessidade de os professores estarem articulados com os coordenadores e abrirem um espaço para que ambos se posicionem nos aspectos profissionais, e possam, assim, permitir que aflorem as questões vividas. Portanto, esta intenção fica clara, na voz de Almeida (2009, p. 85), quando afirma que:

[...] o dar ao outro a possibilidade de posicionar-se como pessoa - significa aceitar que seu desempenho não depende tanto do que sabe, ou não sabe, mas do que é, de sua relação com o saber, com o aluno, com o colega, com a escola, com a profissão. É preciso que haja espaço para ser ouvido, para falar [...].

Outro ponto essencial foi analisado nessa categoria: as participantes deveriam assinalar se a escola em que atuam promove o relacionamento harmonioso entre os profissionais, melhorando o processo ensino-aprendizagem. Deve-se enfatizar que trinta e três docentes assinalaram que a escola promove o relacionamento harmonioso, enquanto onze professoras afirmaram que não. 
A maioria das participantes disse acreditar que as relações interpessoais na escola determinam a qualidade do trabalho pedagógico e, por isso, professores, diretores e coordenadores devem primar pelo convívio harmônico, minimizando a competição. Contudo, quatro regentes não concordaram que essas relações seriam responsáveis pela qualidade do trabalho pedagógico.

Percebeu-se que quatro professoras salientaram que não existe troca de experiências na escola onde trabalham, mas, as demais participantes afirmaram haver, na instituição onde atuam, troca de ideias e de experiências para enriquecer o trabalho pedagógico da escola. Dezoito docentes afirmaram que são incentivadas a buscar informações e atuar por si próprias. Quando questionadas acerca do posicionamento que a escola deve ter quanto ao relacionamento harmonioso entre profissionais, família e alunos, somente uma participante revelou que tal posicionamento não existe na escola em que trabalha.

\subsubsection{Formação para o trabalho}

Em relação aos cursos realizados na área de Educação Infantil, quatro professoras não responderam a essa pergunta, uma docente afirmou não ter feito curso na área, e as demais participantes declararam que fizeram, pelo menos, um curso em Educação Infantil.

Outro fator fundamental para a pesquisa foi saber a opinião das participantes quanto aos conteúdos ministrados no curso de Pedagogia e a realidade encontrada nas escolas. Em se tratando desse aspecto, vale ressaltar que as professoras foram unânimes em afirmar que existe uma longa distância entre a teoria ensinada na graduação e a prática vivenciada em sala de aula. As participantes afirmaram acreditar que a teoria complementa a prática, mas que falta a contextualização com as condições reais de ensino e aprendizagem nas escolas. Não obstante, uma participante afirmou que o período de estágio foi importante para mostrar aos discentes que tipo de realidade encontrariam, direcionando-os, assim, à prática.

Em relação à necessidade que as professoras sentem de mais formação para desenvolverem um bom trabalho pedagógico na escola em que atuam, nove profissionais afirmaram encontrarem-se nessa situação. A mesma quantidade de docentes (nove) assegurou estar satisfeita com sua preparação para atuar na 
Educação Infantil e dez participantes revelaram que sempre realizam cursos voltados para a Educação Infantil. Dentre estas, quatro docentes concordaram que as teorias ou tendências pedagógicas estudadas durante a graduação nada têm a ver com a realidade escolar em que atuam. É importante lembrar que:

Pensar a prática não é somente pensar a ação pedagógica na sala de aula, nem mesmo a colaboração didática com os colegas. É pensar a profissão, a carreira, as relações de trabalho e de poder nas organizações escolares, a parte de autonomia e de responsabilidade conferidas aos professores, individual ou coletivamente (PERRENOUD, 1995, p. 200).

Quanto ao curso de Pedagogia como formador do educador, onze professoras disseram acreditar ser o percurso mais indicado para os profissionais que pretendem atuar na Educação Infantil.

A formação continuada enfatizada pelas professoras significa que "[...] estar em formação implica investimento pessoal, um trabalho livre e criativo sobre os percursos e sobre os projetos próprios com vista à construção de uma identidade, que é também uma identidade profissional" (NÓVOA, 1995, p. 25).

Quando foi discutida a valorização do trabalho realizado na Educação Infantil, apenas três professoras afirmaram que isso ocorre; três concordaram que é uma função muito estressante e quatorze afirmaram que o trabalho pedagógico na Educação Infantil é excessivamente mais exigente que nas demais modalidades de ensino, portanto, deveria ser mais bem remunerado.

Mesmo conhecendo todas as dificuldades inerentes ao magistério, a maioria das participantes está satisfeita com a profissão que escolheu e apenas duas regentes afirmaram que deixarão a Educação Infantil quando conseguirem outro emprego.

\subsubsection{Considerações finais}

Pode-se perceber por este trabalho que, no que tange à formação acadêmica das docentes das escolas particulares, dez fizeram apenas o magistério e, dezessete concluíram a graduação. Outras onze professoras fizeram pós-graduação e seis entrevistadas não responderam a esta pergunta, o que possibilita a conclusão de que 
os professores desse nível de ensino estão preparados para a docência no tocante à formação profissional.

Em relação ao tempo de experiência das participantes na Educação Infantil, verificou-se que a maioria se encontrava com mais de quatro anos na regência nesta modalidade de ensino, apesar de que, se verificada a faixa etária, percebeu-se que a predominância estava com professores de até três anos de experiência.

Foi importante perceber que, apesar de todas as dificuldades inerentes ao magistério, e as professoras vivenciam isto, a maioria das participantes está satisfeita com a profissão que escolheu e apenas duas regentes afirmaram que deixarão a Educação Infantil quando conseguirem outro emprego.

As principais características e atributos de um professor de Educação Infantil destacados pelas participantes devem ser: amor, carinho e paciência - em primeiro lugar - e, em segundo, a formação adequada para a atuação nessa modalidade de ensino e o conhecimento da faixa etária das crianças.

A formação continuada é promovida nas instituições onde trabalham vinte e oito docentes, enquanto para dezesseis participantes não há a promoção dessa formação. Sete docentes afirmaram que as teorias ou tendências pedagógicas estudadas durante a graduação nada têm a ver com a realidade escolar em que atuam. As participantes consideram ser fundamental a participação da família na elaboração e na intervenção do projeto político pedagógico da escola, apesar de não se contar sistematicamente com a presença da família nas reuniões escolares.

A adaptação da criança ao ambiente de sala de aula de Educação Infantil é uma das principais dificuldades destacadas pelos professores, sendo apresentadas, ainda, as faltas de limites e de respeito como maiores dificuldades.

Pelos dados apresentados, percebeu-se que a maior dificuldade que os professores sentem em relação aos coordenadores está na falta de comunicação clara e objetiva, bem como a falta de diálogo e o despreparo do gestor para lidar com situações cotidianas da Educação Infantil. A falta de liberdade e a dificuldade de expor novas ideias também foram apontadas como empecilhos nessa relação. A maioria das participantes afirmou acreditar que as relações interpessoais na escola 
determinam a qualidade do trabalho pedagógico e, por isso, professores, diretores e coordenadores devem primar pelo convívio harmônico, minimizando a competição.

Considerou-se que, pelo número de professoras que participaram da pesquisa, pode-se estabelecer uma percepção indicativa da situação da Educação Infantil no Distrito Federal.

Esta pesquisa faz parte de uma pesquisa maior que abrangerá também a participação de professores de escolas públicas. Vale ressaltar que já foram realizadas pesquisas com gestores e pais das escolas públicas e particulares. Todos esses dados reunidos aprofundaram os resultados da pesquisa, uma vez que se pretende, ao final, obter resultados contributivos para melhoria do processo de formação do educador no Distrito Federal e a divulgação dos resultados em eventos e em periódicos científicos, em nível regional, nacional e internacional.

Esses resultados poderão servir de base para reflexões entre profissionais desse nível de ensino e fornecer elementos que contribuam com as instituições de Educação Infantil, abrindo oportunidades para a continuação dos estudos, levando a novos projetos, seminários, fóruns e debates. 


\section{O GESTOR DA EDUCAÇÃO INFANTIL}

\subsection{De escolas públicas e particulares}

Este artigo apresenta resultados de uma pesquisa que teve como objeto apresentar e analisar a percepção do gestor quanto às expectativas e às necessidades da Educação Infantil. Esta pesquisa foi realizada em seis escolas particulares e seis escolas públicas que atuavam na área da educação infantil. Entretanto, os dados quanto ao gestor foram analisados de forma conjunta, de escolas particulares e públicas. As categorias selecionadas foram: a caracterização dos participantes da pesquisa; o trabalho pedagógico; as relações interpessoais; a formação para o trabalho e a realidade escolar. Percebeu-se, então, que existe a formação acadêmica e a formação continuada para o trabalho de gestor e que o curso de Pedagogia, apesar de essencial para a formação dos educadores, enfatiza a teoria. Espera-se, com este trabalho, proporcionar subsídios para que profissionais da educação infantil possam contribuir com o trabalho pedagógico da Educação Infantil.

\subsubsection{Situando o Assunto}

O tema deste trabalho versa acerca das necessidades e das expectativas da educação infantil e da formação do pedagogo para atuar neste nível de ensino. Pretende investigar, diante das mudanças governamentais realizadas nos últimos dez anos, se as diretrizes para a formação do profissional que irá atuar na Educação Infantil encontram-se coerentes com a realidade da educação infantil do Distrito Federal. O curso de Pedagogia, como um dos principais mediadores dessa relação, será também, portanto, objeto de investigação em sua proposta curricular. Compreende-se como educação infantil aquela que atende pedagogicamente o período de vida escolar de crianças com idade entre zero e cinco anos, isto com a implantação do ensino fundamental de nove anos.

De acordo com a Lei de Diretrizes e Bases da Educação Nacional - LDB 9.394/96 (BRASIL.MEC, 1996), a instituição educacional que atende crianças de 0 a 3 anos é denominada de creche; e a que atende crianças de 4 e 5 anos denomina-se infantil. 
A Constituição Federal da República de 1988 (BRASIL, 1988) determinou, em seu art. 208, inciso IV, que a educação na faixa etária de 4 e 5 anos é dever do Estado e que essa responsabilidade, então, caberia ao antigo curso normal (nível técnico) ou simplesmente magistério de segundo grau. Em vista disso, durante muito tempo jovens professoras aos 18 anos iniciavam a vida profissional, responsabilizando-se pela iniciação acadêmica e pela alfabetização das crianças dessa faixa etária.

Com as alterações oriundas da LDB 9394/96 (BRASIL.MEC, 1996), o magistério de nível técnico foi suprimido, ficando, então, determinado, que todos os professores que atuassem na Educação Infantil deveriam ser graduados. Este processo, além do mais, deveria ter sido concluído por volta do ano 2010.

Como principais desafios desta pesquisa estão sendo investigadas as questões que tratam a respeito dos profissionais que atuam na educação infantil. Assim, questiona-se se estes profissionais sentem-se preparados para lidar com os problemas psicopedagógicos das crianças; como as participações das famílias estão sendo percebidas pelas escolas; se é possível, atualmente, formar pedagogo para atuar com eficácia e eficiência na educação infantil; quais as reais necessidades das crianças e das respectivas famílias e se os profissionais da educação infantil estão sendo preparados para lidar com a diversidade cultural e o processo de inclusão.

Desse modo, o objetivo geral deste trabalho foi investigar, junto à comunidade escolar, as expectativas e as necessidades da Educação Infantil verificando-se a preparação do profissional para atuar nessa área. Os objetivos específicos pretenderam:

Investigar junto ao gestor as expectativas e as necessidades emergentes da comunidade da Educação Infantil;

Verificar a forma de condução do processo de desenvolvimento e de aprendizagem da criança de zero a cinco anos e a coerência com a formação de profissionais para atuarem na área;

Investigar os procedimentos didático-metodológicos utilizados pelos professores e os resultados pedagógicos até então alcançados; 
Propor alternativas para aperfeiçoar o processo de formação do profissional da Educação Infantil tendo em vista as expectativas da comunidade escolar do Distrito Federal.

\subsubsection{Análise e discussão dos dados: principais resultados}

Uma vez terminada a coleta de dados, procurou-se organizá-los de maneira a facilitar a apresentação/compreensão visando à análise e à discussão que se fizeram necessárias. Para isto, foram definidas algumas categorias: a caracterização dos participantes da pesquisa; o trabalho pedagógico; relações interpessoais; formação para o trabalho e realidade escolar.

O questionário, instrumento utilizado para a realização desta coleta, foi elaborado com perguntas abertas e fechadas o que permitiu perceber a situação atual do grupo pesquisado. Notou-se que neste instrumento os participantes demonstraram o que pensavam em relação ao trabalho desenvolvido na educação infantil.

Objetivou-se, na medida do possível, extrapolar a mera descrição do conteúdo do instrumento, buscando-se aprofundar a interpretação das respostas e, assim, construir o conhecimento.

Com base no que foi coletado procurou-se evidenciar a visão dos gestores acerca da formação do educador infantil e as expectativas e as necessidades das escolas. Nesse sentido, não se pode pensar que um gestor não preparado assuma essa atribuição e responsabilidade, em vista da necessidade de compreender que a atuação dele deve voltar-se para a área pedagógica. Para Libâneo (2013b, p. 339), a gestão democrática "não pode ficar restrita ao discurso da participação e suas formas externas - as eleições, assembleias e reuniões. Ela está a serviço dos objetivos do ensino, especialmente da qualidade cognitiva dos processos de ensino aprendizagem".

Considerou-se necessário levantar alguns traços característicos desses profissionais que têm como atribuições, pelo cargo que ocupam, a responsabilidade de organizar a escola para que o trabalho docente possa ser de qualidade, de comprometimento social e ético, de responsabilidade com os valores a serem 
formados nos alunos. Para isto, tomou-se por base referências importantes como idade, sexo, experiência profissional (experiência docente, tempo de atuação e formação acadêmica), cujos resultados foram apresentados e analisados neste trabalho.

\subsubsection{A caracterização dos participantes da pesquisa}

A caracterização dos gestores das escolas públicas e particulares evidencia que todos os participantes são do sexo feminino. Percebeu-se que a faixa etária predominante na escola pública é de 31 a 40 anos e no que se refere à escola particular há variedade na faixa etária com tendência a serem mais jovens. No entanto, houve equivalência nos dados dos gestores no que se refere à faixa etária entre 51 e 60 anos.

Quanto à formação acadêmica (graduação, especialização, mestrado e doutorado), todas são graduadas, a maior parte em Pedagogia, sendo uma das gestoras da escola particular habilitada em Pedagogia e em Psicologia. As gestoras das escolas públicas fizeram pós-graduação lato sensu em Fundamentos Teóricos da Prática Pedagógica e em Administração Pública Escolar. As participantes da instituição particular relataram que a pós-graduação concluída foi em Psicopedagogia, Educação Infantil e Psicopatologia Lacaniana.

O tempo de formação nas escolas públicas e particulares variou de quatro a dezessete anos. Destaca-se que uma das pesquisadas da escola particular concluiu a pós-graduação somente há dois anos e outra há mais de vinte e cinco anos. Na coleta de dados das escolas particulares foi observada diferenciação da conclusão da formação acadêmica. A importância do tempo de magistério para esta pesquisa decorreu do fato de que não se trata apenas de elencar os dados numéricos, mas de também investigar e caracterizar a qualidade profissional dos gestores que atuam na Educação Infantil.

Em relação ao tempo e à experiência na educação infantil (docência e coordenação) as pesquisadas afirmaram atuarem entre cinco a trinta anos na escola pública e entre doze e vinte cinco anos, na particular. 
Diante dos dados observados pode-se afirmar que essas gestoras têm conhecimento e identidade já consolidados, para trabalhar com a Educação Infantil, porém isto não significa "acabada". Entende-se por identidade profissional, de acordo com Libâneo (2013a, p. 68), “o conjunto de conhecimentos, habilidades, atitudes e valores que definem e orientam a especificidade do trabalho de professor".

Os dados obtidos junto aos gestores da rede pública revelam que os cursos de curta duração realizados na área de educação infantil podem ser elencados da seguinte forma: Atualização e planejamento; Aperfeiçoamento para professores de deficientes auditivos; Educação Física e recreação; Proposta pedagógica; Português - séries iniciais e outros; Alfabetização; Parâmetros Curriculares Nacionais (PCN); Programa Formação Professores Alfabetizadores (PROFA); Alfabetização em jogos para o magistério e A arte de contar histórias construindo o saber. No que se refere à escola particular não ficou caracterizado, especificamente, os nomes dos cursos realizados na área de educação infantil. Contudo, uma respondente refere ter realizado cursos de curta duração voltados à Psicomotricidade e à teoria de Maria Montessori.

Os cursos apresentados revelaram o interesse dos profissionais em se atualizarem para melhor desempenho nas práticas cotidianas. De maneira geral, estão voltados para orientar os docentes para o exercício de práticas diferenciadas em sala de aula.

Uma formação permanente, que se prolonga por toda a vida, torna-se crucial numa profissão que lida com saberes e com a formação humana, numa época em que se renovam os currículos, introduzem-se as novas tecnologias, modificam-se os comportamentos da infância e da juventude, acentuam-se os problemas sociais e econômicos. (LIBÂNEO, 2013a, p. 131).

Questionados a respeito do desenvolvimento dos projetos no âmbito da educação infantil, os gestores da rede pública enfatizaram que a escola desenvolve projetos de reagrupamento e de participação em trabalhos realizados pelo MEC acerca da inclusão de alunos deficientes auditivos no ensino regular. Outros pesquisados declararam apenas "SIM", mas não evidenciaram nomes dos projetos; outros não responderam. Percebe-se que há coerência entre os cursos realizados e o trabalho desenvolvido nas escolas pelos gestores. 


\subsubsection{O trabalho pedagógico}

A respeito da condição de coordenador e da percepção quanto aos projetos elaborados pelos professores, três gestores das escolas públicas não responderam. Contudo, dois gestores afirmaram que os projetos são realizados em coletividade e não individualmente. Nas escolas particulares três gestores descreveram, de forma superficial, executar poucos projetos, de pequena extensão e de rápida execução, mas com objetivos claros.

Vale ressaltar que os gestores abordaram que os professores, em sua maioria, não desenvolveram habilidade de pensar e de planejar com autonomia. Em relação à quantidade de projetos executados na escola durante o ano, um gestor menciona que vinte projetos foram desenvolvidos, não necessariamente isolados, mas com outros "segmentos do colégio"; apenas um gestor não respondeu. Oliveira (2010, p. 238), com relação aos projetos didáticos, afirma que eles:

organizam-se segundo temas sobre os quais as crianças vão tecer as redes de significações. São postos como estratégias de ensino que buscam superar uma visão de estabilidade e transparência do ambiente em que elas estão inseridas, o qual apenas precisaria ser conhecido. Abrem possibilidades para cada criança indagar, criar relações e entender a natureza cognitiva, estéticas, política e ética de seu ambiente, atribuindo-lhe significados.

Na escola pública, no que se refere aos principais atributos de um professor que atua na educação infantil variaram as respostas. Foram apresentadas da seguinte maneira: dedicação, persistência, criatividade e envolvimento; gostar do que faz; paciência; ter comprometimento; interessado; formação na área; dinamismo; organizado; alegre; produtividade; disponibilidade; articulação e inovação e afinidade com o trabalho com crianças pequenas.

Os gestores das escolas particulares apontaram atributos essenciais para um professor que atua na educação infantil. Um deles seria "ter consciência da escolha da profissão". Desempenhar o trabalho com autonomia, resolver problemas, ser competente, ter compromisso, ser ágil, bem como proporcionar a criação de vínculo afetivo, também foram citados pelos respondentes. 
A amorosidade e a afetividade foram apontadas como principais atributos de uma professora da educação infantil. Neste sentido, Freire (2011), de maneira poética, estabelece que, querer bem ao aluno, não significa a professora obrigar-se a querer bem a todos os alunos de maneira igual, mas que a afetividade não pode deixar de se expressar na prática pedagógica. Acrescenta ainda que, não precisa haver separação radical entre seriedade docente e afetividade, visto que:

[...] não serei tão melhor professor quanto mais severo, mais frio, mais distante e "cinzento" me ponha nas minhas relações com os alunos, [...] a afetividade não se acha excluída da cognoscibilidade. O que não posso obviamente permitir é que minha afetividade interfira no cumprimento ético do meu dever de professor no exercício de minha autoridade. (FREIRE, 2011, p. 159-160).

Ressalta-se, além do mais, que estes atributos não podem ser vistos isoladamente, sem considerar o ambiente cultural e o componente pessoal dos respondentes. Depende, conforme Wechsler (2003), dos seguintes elementos: motivo, quando o indivíduo deseja ser criativo e crê nesta possibilidade; os meios, isto é, quando a pessoa tem habilidades necessárias e conhecimentos apropriados; e por último, a oportunidade, em que a pessoa tem a consciência do próprio potencial, criando as oportunidades e lidando com as pressões da criatividade no social.

As respostas apresentadas pelos gestores são essenciais para que haja o trabalho coerente e participativo na escola, porém há de se destacar que nem todos os professores têm esses quesitos e conseguem realizar trabalhos de qualidade com as crianças. Esses atributos de forma geral são adquiridos também no decorrer da vivência pedagógica na escola e na sala de aula. Portanto, para Libâneo (2013b, p.179), os papéis do coordenador e da direção são "funções típicas dos profissionais que respondem por uma área ou setor da escola tanto no âmbito administrativo quanto no âmbito pedagógico" e, juntos, devem unir-se para melhor desempenhar o trabalho a ser realizado.

Outro fator importante para a pesquisa foi o item que apresenta e destaca as principais dificuldades dos professores em relação à educação infantil. Os gestores das escolas públicas citaram as "classes heterogêneas que apesar de os alunos estarem agrupados por idade, as dificuldades surgem devido às diferenças quanto à maturidade cognitiva e emocional"; "falta mais reconhecimento por parte da 
sociedade: nossa escola não é creche!"; falta de utilização de material concreto; "fazer uso do lúdico na proposta pedagógica"; "carência de uma formação específica; desconhecem aspectos relevantes do desenvolvimento infantil" e "instabilidade familiar (transferência de responsabilidade)".

Vale ressaltar aqui que, para Piaget (2003), o processo de desenvolvimento da criança passa por estágios, tais como: Sensório-Motor 0-2 anos, Pré-Operatório 2-7 anos, Operatório 7-11 anos e Operatório-Formal 12 anos em diante. De acordo com Goulart (2005), após o estágio sensório-motor, vem o estágio pré-operatório, que corresponde à faixa etária de dois anos até aproximadamente sete anos de idade. Neste estágio, há um grande avanço do desenvolvimento, pois é quando na criança há o aparecimento da função simbólica ou semiótica, ou seja há o surgimento da linguagem. Assim sendo, o sujeito se socializa mais, pois consegue comunicar-se com os demais (chamada por Piaget de socialização da ação)

Segundo Fonseca (1986), há uma longa tradição de arranjos informais de cuidados às crianças. Esta prática também conhecida como circulação de crianças é definida pela autora como a transferência da responsabilidade de nutrição de uma criança de um adulto para outro.

Também os gestores das escolas particulares descreveram diferentemente as dificuldades na docência como, por exemplo, "a pouca importância dada à fase do desenvolvimento da criança, inclusive pelos próprios professores, além da formação de péssima qualidade, uma vez que é voltada fundamentalmente para o ensino fundamental”; "brinquedos pedagógicos"; "recursos áudio visuais, vínculos com os pais"; "saber trabalhar de forma eficiente com inclusão escolar para todos nós é um grande desafio"; e "baixos salários levam às baixas condições de cresceram (cursos, workshops etc.)“.

Pode-se perceber, dentre as dificuldades citadas, que os gestores fizeram referência à aparente tendência de os cursos de formação de professores priorizarem a qualificação profissional dos docentes ao ensino fundamental em detrimento de uma formação orientada à educação infantil.

Acerca desta constatação, novos questionamentos surgem: será que isto ocorre, por ser o ensino fundamental o único nível de ensino obrigatório, segundo a 
atual LDB 9394/1996 (art. 26, inciso I, alínea b) (BRASIL.MEC, 1996), será que nos cursos de formação de professores os docentes responsáveis pelas disciplinas voltadas à educação infantil, dominam pouco os conhecimentos e as competências desse importante nível de ensino? Será ainda, que na concepção pedagógica dos cursos de formação de professores, este nível de ensino não é consideravelmente relevante para a formação da criança em desenvolvimento? Estas, entre outras questões, certamente devem ser levadas em conta ao se propor um curso de formação de professores à comunidade. Até 2013 o ensino fundamental era a única etapa obrigatória. Agora, com a LDB atualizada, a obrigatoriedade se estende também às demais, desde à pré-escola até o ensino médio.

Quanto aos brinquedos pedagógicos e recursos audiovisuais, citados pelos respondentes, são recursos valiosos e indispensáveis, pois correspondem também ao fato de o docente empregar uma diversidade de ferramentas em sua didática de modo a facilitar a aquisição das aprendizagens pelos alunos. Os recursos de ensino no cotidiano da sala de aula constituem mediações na relação aluno-conhecimento, via professor, favorecendo situações de aprendizagem e possibilitando o crescimento do aluno em diferentes dimensões da sua formação. Outro aspecto citado pelos gestores e que merece destaque diz respeito à inviabilização da capacitação dos docentes tendo em vista os baixos salários deles. O piso salarial dos professores para 2020 ficou em R\$ 2.888,24, após um reajuste de 12,84\%.

Compreende-se que existe, por parte dos gestores, o compromisso de realizar o trabalho, porém há falta de determinados aspectos que ainda são insuficientes na hora de viabilizar e de concretizar o que se deseja na escola. Em relação à interpretação dos dados quanto à categoria - temas que devem ser trabalhados na educação infantil, além dos conteúdos específicos, os gestores das escolas públicas ressaltam que devem ser relacionados aos interesses dos alunos de acordo com a faixa etária e da realidade em que vivem; que é preciso trabalhar valores morais e sociais; que se faz necessário estudar a respeito do preconceito e das diferenças sociais, da criatividade, do trabalho lúdico, da musicalidade, do teatro e da psicomotricidade. No entanto, um gestor afirmou que o currículo já privilegia o que é essencial para o trabalho na Educação Infantil. Os temas trazidos pelos gestores das escolas particulares enfatizam a preparação para a vida no sentido do "indivíduo 
autônomo e crítico", a parceria e o convívio com a sociedade, a tecnologia, a natureza, a diversidade cultural, a inclusão escolar, a evolução do grafismo e o desenho infantil e a "valorizar e integrar mais e mais os pais na escola, envolvendoos nos projetos, em festas, eventos".

A escola nesse contexto é vista como responsável juntamente com os pais para a formação da criança. Esse ser humano pequeno, que um dia irá se desenvolver e virá a tornar-se um adulto, necessita da construção do conhecimento, que pode ser vista como uma emergência dos relacionamentos intersubjetivos que retroagem sobre os sujeitos individuais e coletivos que, por sua vez, alimentam as redes construindo novos conhecimentos. Segundo Hernandez (2005), as subjetividades individual e social são construídas na inter-relação do ser humano com seus contextos social e natural, no marco de sua atividade cotidiana, sendo então um produto histórico-cultural.

Toda a construção, condensada na produção cultural (ideológica, espiritual e material) constitui o conjunto de práticas, tradições, crenças, valores, sentimentos, estereótipos, representações etc. que formam o substrato da subjetividade social, no qual a formação do senso comum cotidiano, as manifestações do inconsciente coletivo e a intencionalidade dos sujeitos sociais se expressam os graus de auto-repressão ou autonomia social que possibilitam o contexto. (HERNANDEZ, 2005, p. 83).

Quanto à categoria qualidade do trabalho que os professores desenvolvem com os alunos nessa escola, os gestores das escolas públicas mencionaram “excelente", “muito boa" e "ótima”. Apenas um não respondeu. Dois justificaram que poderia ser melhor se houvesse mais empenho dos professores e que o fato de os profissionais não serem mais capacitados faz com que o trabalho seja insuficiente. Apenas um gestor da escola particular, mesmo considerando que o nível é mais alto que de outras instituições de ensino, acredita que poderia ser melhor. Destaca-se, ainda, que a fala de um gestor evidencia que "estamos em constante estudo teórico que é compartilhado com o aprendizado da prática. Pelos dados apresentados, percebeu-se que há comprometimento e interesse por parte de quem atua na Educação Infantil, sobretudo a partir da LDB 9394/96 (BRASIL.MEC, 1996), que suprimiu o magistério de nível técnico passando a exigir que todos os professores 
que atuarão na Educação Infantil, sejam graduados. Essa situação deverá, certamente, levar à abordagem pedagógica de qualidade.

$\mathrm{Na}$ categoria o "educar" e o "cuidar" na instituição a maioria dos participantes da escola pública respondeu que consegue estabelecer esta relação e diferenciar quando necessário uma da outra, complementando que o "educar e o cuidar precisam estar juntos para a formação integral do aluno e que os dois termos se confundem, por isso fazemos tudo ao mesmo tempo.”

A escola particular, em outras palavras, apresentou ideias relativamente similares, reforçando que o educar e o cuidar devem ser dosados. Contudo, deve-se destacar a subjetividade do gestor em suas justificativas: "deve-se educar os pais" quanto a essa diferenciação; "o cuidar está ligado à emoção e à auto-expressão"; o educar está relacionado ao cognitivo e o cuidar refere-se ao cuidado das relações afetivas; e, ainda, que cuidar é "crecheiro" e educar é "modelagem”.

\subsubsection{Relações Interpessoais}

Para o tópico o ambiente de sala de aula e as principais dificuldades de relacionamento encontradas entre: professor e aluno; aluno e aluno; professor e pai ou responsáveis; professor e coordenação da escola foram organizados dados dos pesquisados de acordo com cada um dos itens apresentados acima.

Para a categoria professor-aluno, nas escolas públicas, os pesquisados declararam que há "problemas de disciplina gerados por alunos sem disciplina e sem limites". Outros pesquisados evidenciaram "falta de diálogo e de afetividade"; "falta de limites em casa o que reflete em rebeldia em sala de aula" e, ainda, "falta de compreensão e de atenção"; e "autoritarismo". Nas escolas particulares uma gestora não apresentou resposta, contudo os outros destacaram várias dificuldades: "de personalidade e de empatia, sobretudo do professor, que não consegue identificar os preferidos e os preteridos e prejudica suas crianças”; “em administrar estratégias dentro do contexto de sala de aula"; "como trabalhar com alunos hiperativos (muitas vezes estressam o professor que não encontra muita ajuda da família ou dos especialistas)"; "domínio"; e uma gestora relata não ter dificuldade, "mas à empatia e vínculo entre duas partes são de fundamental importância”. O papel do professor na Educação Infantil é de extrema importância uma vez que ele atua como: 
mediador das relações entre as crianças e dos diversos universos sociais nos quais elas interagem, possibilita a criação de condições para que elas possam, gradativamente, desenvolver capacidades à tomada de decisões, à construção de regras, à cooperação, à solidariedade, ao diálogo, ao respeito a si mesmas e ao outro, assim como desenvolver sentimentos de justiça e ações de cuidados para consigo e para os outros (RCNEI, 1998, p. 43, v.2).

Em relação ao item aluno-aluno, os gestores das escolas públicas responderam que há entre os alunos: "desentendimentos e pequenas brigas disputando liderança ou brinquedos"; falta o "respeito ao próximo" e o "companheirismo" e bom "relacionamento interpessoal"; que existe "agressividade" e "discriminação (por exemplo, em relação à criança obesa, meninos de cabelo grande)". Os gestores das escolas particulares concordaram no quesito "respeito", mas acrescentaram que as dificuldades só ocorrem "se o professor não souber interferir adequadamente"; falaram em termos de postura "egocêntrica" e de "temperamento". Uma gestora acredita que para ocorrer a "socialização", deve acontecer "um processo em longo prazo (durante três anos)".

Na relação professor-pai ou responsáveis, foi apresentado pelos gestores das escolas públicas: "o envolvimento dos pais nos trabalhos escolares"; "a dificuldade dos pais em atender e executar orientações dadas pelos professores, psicólogos e coordenadores"; a questão do "tempo, do diálogo e da participação". Na escola particular "o pai deve assumir seu papel" e ainda colaborar, "entender as responsabilidades de ambas as partes" e, ainda, valorizar e reconhecer "o professor como profissional da educação."

Na parte que envolve professor-coordenação da escola, os gestores das escolas públicas responderam da necessidade de bom relacionamento; que para que essa relação seja possível é necessário que haja professores interessados e envolvidos no trabalho; planejamento e decisões tomadas em parceria professores/coordenadores. Afirmaram, ainda, que os professores devem ter "envolvimento", “disposição, atitude de pesquisa, ética e desafios"; bem como "relação de cooperativismo". Os gestores das escolas particulares diversificaram-se nas respostas. Salientaram que se deve "aceitar as diferenças"; "ser positivo e produtivo"; "saber trabalhar em equipe". Destacou-se, ainda, a falta de preparo dos 
professores e pouco profissionalismo, além da desvalorização do profissional da educação. Contudo, uma gestora não viu dificuldades quanto ao relacionamento professor-coordenação da escola.

Entende-se, a partir dos dados apresentados, haver a preocupação do gestor no sentido de um relacionamento adequado para a melhoria do trabalho a ser realizado na escola. No que tange a conhecer e a acompanhar o desenvolvimento cognitivo, afetivo, psicomotor, social e demais aspectos a serem pesquisados nas crianças que estão na educação infantil, acreditam que deve ser assumido com responsabilidade e envolvimento por todos os parceiros da escola, para que haja crescimento e um relacionamento agradável.

Deve-se enfatizar que, para Vygotsky (2010), os professores, os pais ou os alunos mais desenvolvidos com a utilização dos signos, influenciam no crescimento intelectual das crianças que se encontram em contato com eles, fazendo-as, por meio da aprendizagem, atingir níveis antes não alcançados. Neste sentido, ele afirma que [...] o aprendizado desperta vários processos internos de desenvolvimento, que são capazes de operar somente quando a criança interage com pessoas em seu ambiente e quando em cooperação com seus companheiros. (VYGOTSKY, 2010).

\subsubsection{Formação para o trabalho}

Quanto à categoria a preocupação da instituição de ensino superior com a preparação do professor/gestor para os problemas cotidianos da educação infantil, quatro gestores das escolas públicas afirmaram que "Não" e dois deles que "Sim", todos sem justificativas.

As respostas dos gestores das escolas particulares foram variadas, sendo elas: - três disseram "Não", justificando da seguinte maneira: "o professor é formado teoricamente e com pouco ou nenhuma autonomia. Logo não consegue lidar com os problemas que exigem esses requisitos"; uma afirmou que "em parte", e duas não entenderam a questão.

Continuando a respeito da versão dos gestores acerca do Curso de Pedagogia e a realidade encontrada na escola, todos da escola pública salientaram a deficiência desse curso para a sua formação, com as seguintes alegações: "não deu informações 
ou experiências práticas sobre a realidade encontrada"; "muita teoria, nada a ver", "o curso deixa muito a desejar nos dias de hoje, porém quando fiz, a formação era muito boa"; "as teorias trabalhadas nos cursos de Pedagogia nem sempre são práticas para a realidade da escola e seu dia-a-dia"; "o curso não prepara o pedagogo para a Educação Infantill, e, ainda, "relação entre o sonho e a realidade, dicotomia entre teoria e prática". Quanto à escola particular, três gestores destacaram que o curso não prepara adequadamente o gestor para a Educação Infantil, com os seguintes argumentos: "a educação caminha no sentido contrário do desenvolvimento da humanidade, logo, o curso de Pedagogia não só não prepara para a realidade como não acompanha o mundo real"; "o curso de Pedagogia é essencial para a formação do educador, mas muitas vezes a realidade encontrada na escola fica massacrada"; "o curso infelizmente não retrata a realidade de uma sala de aula”. Quanto aos que afirmaram que o curso prepara para o exercício da profissão, um pontuou que "O curso de Pedagogia é fundamental para atuar na escola"; e dois não se posicionaram. Percebeu-se a partir destes depoimentos, distanciamento entre o que é ensinado e a prática de sala de aula. Segundo Nunes (2008, p. 102), sobre a falta de relação entre a teoria e a prática:

A literatura sugere que os cursos de formação de professores têm um limitado impacto na prática de sala de aula (Richardson, 1994; Landrum, Cook; Tankersley, 2002; Greenwood, 1998; Gersten; Smith-Johnson, 2001; Tardif, 2000; Lüdke; Cruz, 2005). Nesses programas instrucionais, uma série de técnicas e informações são apresentadas de forma desconexa e isolada (Gersten; Smith-Johnson, 2001), tornando difícil a sua implementação em contextos reais.

Na maior parte dos cursos lato sensu, por exemplo, essas informações são expostas e discutidas de forma coletiva, enquanto que a literatura tem sugerido que formas individualizadas de ensino têm apresentado resultados mais promissores na aprendizagem do professor (Langone; Koorland; Oseroff, 1987; Fuchs; Fuchs, 2001; Abbott et al., 1999).

A formação inicial dos gestores, professores e coordenadores deve enfatizar a articulação entre eixos norteadores da resposta pedagógica de nível superior e aproximação com a realidade das escolas locais públicas para que haja intercâmbios relacionados à teoria e prática, ensino e pesquisa, relação professor e aluno, a articulação administrativo-pedagógica. 
Percebe-se, portanto, a grande responsabilidade do profissional da Educação Infantil, que deverá ter um perfil multifacetado para atender às diversas solicitações que a criança exige nessa idade.

\subsubsection{Realidade Escolar}

No que se refere aos problemas enfrentados em sua chegada à educação infantil e se eles foram superados, quatro gestores da escola pública tiveram problemas e assim justificaram suas respostas: "problemas sérios de comportamento de alunos" (mas que houve melhoria); dificuldades de relacionamento entre professores (mas que as disputas deram lugar à parceria); mudança na parte pedagógica (conteúdos-estratégias); e, ainda, funcionários sem habilitação específica para a educação infantil (e que os problemas não foram superados totalmente). Ainda, a "falta de orientação na coordenação". Os demais afirmaram "não encontrei maiores problemas" e "nem me lembro.” A partir dessas respostas observa-se que há variáveis administrativas, familiares e pedagógicas as quais interferem na atuação do gestor na escola durante a realização do trabalho a ser desempenhado.

Comentando a visão afirmativa dos quatro gestores da escola particular, pode-se entender que: "faltou planejamento honesto e coerente; dificuldades de relacionamento do grupo (mas que os problemas foram superados)"; "a família quer que o professor desempenhe papéis destinados a ela"; "não é fácil integrar, pois existem 'diferenças' que são vitais”. Dois gestores não tiveram problemas.

Continuando a análise dos dados, quanto à categoria a escola/infraestrutura e os recursos didáticos necessários ao desenvolvimento e à aprendizagem dos alunos, foi possível elencar três aspectos favoráveis apresentados pelos gestores das escolas públicas. Em sua maioria, apresentaram "Sim" quanto às condições físicas e de infraestrutura da escola, de serem adequadas para atender aos alunos da educação infantil. Outras respostas foram apresentadas, tais como: "ótima estrutura física, "material didático adequado e bons profissionais"; "materiais disponíveis quando se necessita/recursos variados"; "formação continuada e material didático".

Verificou-se unanimidade na visão das gestoras, pelas respostas, quanto às condições da escola para que possam desenvolver adequadamente as atividades que serão propostas. Uma participante respondeu que deve haver "parque, refeitórios, 
salas e mobiliário adequado". Apenas uma participante afirmou "Não", mas não justificou. No que se refere à escola particular, em sua totalidade, os participantes alegaram possuir infraestrutura adequada para funcionamento, tais como: salas de atividades com grande diversidade de material; horta; areia; computador; máquina de escrever; salas de vivência; quadra de esporte; área verde; parquinho; biblioteca com acesso à internet; sala multimídia; e jogos pedagógicos. Um gestor afirmou que a escola proporciona cursos de treinamento, capacitação e acompanhamento.

Quanto à questão dos recursos didáticos, Tacca (2006, p. 48), entende que é preciso haver "estratégias pedagógicas acopladas, enraizadas e nitidamente implicadas com as relações sociais estabelecidas. Nesse sentido, elas seriam recursos relacionados que orientam o professor na criação de canais dialógicos, tendo em vista adentrar o pensamento do aluno, suas emoções conhecendo as interligações impostas pela unidade cognição afeto".

\subsubsection{Considerações finais}

Percebeu-se no trabalho que existe a formação acadêmica para a realização do trabalho de gestor, uma vez que todos os pesquisados fizeram curso superior na área e que, para eles, é importante a formação continuada para a Educação Infantil. Justificaram que realizaram vários cursos de aperfeiçoamento e pós-graduação voltados para o cargo que ocupam.

Dos doze gestores pesquisados, cinco acreditam que a instituição formadora os preparou adequadamente para a função que ocupam na escola. O curso de Pedagogia, apesar dos gestores considerarem essencial para a formação dos educadores, enfatiza a teoria e encontra-se distanciado da realidade. Os gestores têm experiência na área, tendo em torno de cinco a vinte e cinco anos de trabalho com a educação infantil.

Outro elemento a ser destacado, tanto nas escolas públicas quanto nas particulares, diz respeito à importância da participação da família no processo pedagógico dos filhos que frequentam a educação infantil. Mais de uma vez foi salientado de que este nível de ensino da educação básica não serve somente para 
cuidar das crianças ("Cuidar é crecheiro"!), mas educar, contribuindo na formação do sujeito. No entanto, para que isto ocorra, a família deve estar presente e acompanhar a evolução dos filhos.

Os gestores enfrentaram e enfrentam vários problemas no início do trabalho, tais como: indisciplina; relacionamento com professores; falta de orientação; pessoal não habilitado; elaboração do planejamento e relacionamento com os familiares. As maiores dificuldades atuais são: classes heterogêneas, valorização da função da escola, instabilidade afetiva dos alunos, relação familiar, problemas pedagógicos, formação do professor e baixos salários.

Entretanto, consideram que a escola oferece infraestrutura e recursos didáticos necessários ao desenvolvimento e à aprendizagem dos alunos. O trabalho realizado nas escolas, segundo a maioria, é muito bom, mas pode melhorar. Todos os gestores da escola particular e cinco, dos seis da pública, concordaram que a escola oferece as condições necessárias à educação. Todos os gestores têm desenvolvido projetos na área da educação infantil.

No que se refere à assessoria pedagógica foi destacado que há suporte para os professores e acompanhamento de forma eficiente para todos os envolvidos. Os temas, segundo os gestores, que devem ser trabalhados na educação infantil são preferencialmente: valores morais, criatividade, ludicidade, musicalidade, teatro, psicomotricidade, cidadania, tecnologia, diversidade cultural e inclusão escolar.

Todos os gestores da escola pública e cinco da particular concordaram que as relações interpessoais determinam a qualidade do trabalho pedagógico. Segundo eles, os pais devem colaborar na parte de eventos, conservação da escola e no sucesso do processo ensino-aprendizagem dos alunos. Entretanto, na escola particular apenas dois gestores concordaram com essa situação. Na opinião dos gestores os pais devem acompanhar diariamente as tarefas de seus filhos, no que concordaram todos os gestores da escola particular e quatro da escola pública.

Observou-se coerência, clareza e objetividade nas respostas dos gestores. Os resultados apresentados demonstraram envolvimento deles com a educação infantil, que se encontram atentos a tudo o que ocorre na escola e que demonstraram gosto e 
comprometimento com trabalho. O compromisso foi percebido tanto com relação aos aspectos administrativos quanto aos aspectos pedagógicos.

Considera-se que com o número de gestores que participaram da pesquisa pode-se estabelecer uma amostra indicativa da situação da educação infantil no Distrito Federal. Esta é parte de uma pesquisa maior que abrangerá também professores e pais, tanto de escolas públicas quanto de escolas particulares, o que deverá aprofundar os resultados da pesquisa. Pretende-se ao final, os seguintes resultados: contribuir para a melhoria do processo de formação do educador no Distrito Federal e divulgar os resultados em eventos e em periódicos científicos, em nível regional, nacional e internacional.

Esses resultados podem servir de base para discussões entre profissionais de diferentes sistemas de ensino, fornece elementos que contribuam com as instituições de educação infantil, abrindo oportunidades para a continuação dos estudos, levando a novos projetos, seminários, fóruns e debates. 


\section{OS PAIS E A EDUCAÇÃO INFANTIL}

\subsection{De escola pública}

O objeto desta pesquisa foi apresentar a percepção dos pais quanto às expectativas e às necessidades da Educação Infantil. Foi utilizado o método qualitativo, sendo instrumento para coleta de dados alguns questionários respondidos por pais de escolas públicas do Distrito Federal. As categorias selecionadas foram: a caracterização dos participantes da pesquisa; o trabalho pedagógico; as relações interpessoais; a formação para o trabalho e a realidade escolar. Os pais encontram-se atentos e querem educação diferenciada e de qualidade para os seus filhos. Alguns pais salientaram a importância da parceria entre família-escola-governo e a preocupação com a estrutura e com o funcionamento educacional, os quais interferem no desenvolvimento e na aprendizagem da criança. Isto, no entanto, não fez com que os pais se eximissem da responsabilidade na formação de seus filhos, mas atribuíram ao governo a liderança quanto à qualidade do sistema de ensino. Espera-se, com este trabalho, proporcionar subsídios para que profissionais da educação infantil possam contribuir com o trabalho pedagógico da Educação Infantil.

\subsubsection{Situando o Assunto}

O tema deste trabalho versa acerca das necessidades e das expectativas da educação infantil e da formação do professor para atuar neste nível de ensino, por intermédio da fala de pais. Pretende também investigar, diante das mudanças governamentais realizadas nos últimos dez anos, se o profissional que atua na Educação Infantil encontra-se preparado diante da realidade da educação infantil do Distrito Federal.

Compreende-se como educação infantil aquela que atende pedagogicamente o período de vida escolar de crianças com idade entre 0 e 5 anos, isto com a implantação do ensino fundamental de nove anos. Entretanto, este trabalho enfatiza o período de 3 a 5 anos.

De acordo com a Lei de Diretrizes e Bases da Educação Nacional (LDB) 9.394/96 
(BRASIL.MEC, 1996), a instituição educacional que atende crianças de 0 a 3 anos é denominada de creche e a que atende crianças de 4 e 5 anos denomina-se infantil.

A Constituição Federal da República de 1988 (BRASIL, 1988) determinou, em seu art. 208, inciso IV, que a educação na faixa etária de 4 e 5 anos é dever do Estado e que essa responsabilidade, então, caberia ao antigo curso normal (nível técnico) ou simplesmente magistério de segundo grau.

Com as alterações oriundas da LDB 9394/96 (BRASIL.MEC, 1996), o magistério de nível técnico foi suprimido, ficando determinado que todos os professores que atuassem na Educação Infantil deveriam ser graduados.

Desse modo, o objetivo geral deste trabalho foi investigar, junto aos pais, as expectativas e as necessidades da Educação Infantil verificando-se também a preparação do profissional para atuar nesse nível de ensino. Os objetivos específicos pretenderam:

Investigar junto aos pais as expectativas e as necessidades que emergem da comunidade familiar com relação à Educação Infantil;

Investigar os procedimentos didático-metodológicos utilizados pelos professores e os resultados pedagógicos até então alcançados;

Verificar a opinião dos pais quanto à preparação dos profissionais que atuam na educação infantil;

Propor alternativas para aperfeiçoar o processo de formação do profissional da Educação Infantil tendo em vista as expectativas da comunidade escolar do Distrito Federal.

Considerou-se necessário para o alcance dos objetivos questionar aos pais sobre as principais atribuições do professor; sobre o papel da escola; as atitudes dos docentes; a responsabilidade dos professores junto aos alunos; a contribuição dos pais ou responsáveis em relação ao desenvolvimento global da criança; a estrutura e o funcionamento da escola; a preparação dos professores; o relacionamento escolapais e a qualidade de ensino. 


\subsubsection{Análise e discussão dos dados: principais resultados}

Os resultados serão apresentados abaixo nas categorias propostas:

\subsubsection{A caracterização dos participantes da pesquisa}

Quanto à caracterização dos pais das escolas públicas, evidenciou-se que, dos 16 (dezesseis) entrevistados, 13 (treze) são do sexo feminino e 3 (três) do masculino. Constatou-se que a faixa etária de 7 (sete) pais encontrava-se entre 31-40 anos; de 5 (cinco) pais entre 41-50 anos; de 3 (três) pais entre 20-30 anos e apenas 1 (um) pai entre 51-60 anos.

Quanto à formação acadêmica ou grau de escolaridade, predominou o ensino médio completo com 5 (cinco) pais e 1 (um) com esse nível de ensino incompleto. Quanto ao ensino fundamental, 3 (três) pais o concluíram e 1 (um) não o completou. $\mathrm{O}$ curso de graduação foi representado por 4 (quatro) pais e 2 (dois) pais apresentaram sua escolaridade.

Em relação à profissão que os pais exercem, foram descritas diversas profissões, como: carteiro, técnica em enfermagem, vendedor, cozinheira, servidor público, auxiliar de serviços gerais, enfermeiro, professor, diarista, dona de casa, assistente administrativo e auxiliar de monitoria. Ressalta-se que 4 (quatro) pais não responderam a esse item.

Diante dos dados observados, notou-se pela formação acadêmica dos pais há uma relação com o que reza a Constituição Federal de 1988 (BRASIL, 1988), em seu inciso XXV, do Art. $7^{\circ}$, do Capítulo II, sobre os Direitos Sociais, do Título I, dos princípios fundamentais, de que são direitos dos trabalhadores urbanos e rurais, além de outros que visem à melhoria de sua condição social a assistência gratuita dos filhos e dos dependentes desde o nascimento até seis anos de idade em creches e préescolas, o que vai garantir maior cidadania a essas crianças.

\subsubsection{O trabalho pedagógico}

A respeito do principal atributo que deve ter um professor da Educação Infantil, os pais ressaltaram várias características, que julgam essenciais e que devem estar presentes no perfil do profissional de educação infantil: cinco pais relataram "a 
paciência"; quatro pais descreveram que ser "criativo"; três pais disseram "que tem que gostar do que faz/profissão"; dois pais afirmaram que "tem que gostar de criança"; dois pais estão de acordo que "atenção" é prioridade, e todos os pais acrescentaram que ser "alegre", “dedicado", “competente”, "dinâmico", “atualizado", "responsável”, “comprometido", "carinhoso", e "ter formação para atuar como professor de Educação Infantil” é fundamental.

Quanto ao papel da escola na formação dos filhos, cinco pais concordaram que o aprendizado sobre cidadania, formação intelectual, desenvolvimento social e afetivo, tem fundamental importância no processo educativo de seu filho; enquanto quatro pais mencionaram que a escola é importante; um pai não respondeu à questão e os demais deram respostas como "a escola tem o papel de ajudar a criança a desenvolver suas habilidades e adquirir conhecimentos" e "vejo como um complemento na educação de meu filho, pois escola e família têm que andar junto". Em relação a esse aspecto, Libâneo (2013a, p. 16-17) enfatiza que:

O trabalho docente é parte integrante do processo educativo mais global pelo quais os membros da sociedade são preparados para a participação na vida social. A educação - ou seja, a prática educativa - é um fenômeno social e universal, sendo uma atividade humana necessária à existência e funcionamento de todas as sociedades. Cada sociedade precisa cuidar da formação dos indivíduos, auxiliarem no desenvolvimento de suas capacidades físicas e espirituais, prepará-los para a participação ativa e transformadora nas várias instâncias da vida social.

Sobre indisciplina, dez pais afirmaram que os professores devem comunicar em primeiro lugar a família sobre o ocorrido; entretanto, seis pais alegaram que cabe ao professor e à escola tomar as providências, tais como: "ser firme, e não ceder quando existir choro"; "corrigir"; "levar à direção"; "impor limites, e ter postura"; que "deveria ser como antigamente-castigo, rigor na punição"; "chamar atenção, sem humilhar diante dos outros" e "falar em particular fora da reunião".

Quanto à educação inclusiva, destacou-se um relato acerca do tratamento quanto de um deficiente auditivo não havendo distinção no tratamento em relação aos outros alunos.

Indubitavelmente, o papel do educador ficou evidente quando foi perguntado qual deve ser a responsabilidade do professor quando está com o seu (sua) filho (a). 
Seis pais declararam que educar e ensinar são indispensáveis para um educador. Vale ressaltar frases ditas por dois pais: "desenvolver metas de aprendizagem, buscando sempre novos materiais e ideias" e "o professor deve estar comprometido com o aprendizado de todos ao mesmo tempo, considerando para isso metodologias diversificadas". Ficou explícito, entretanto, entre seis pais, que algumas características que são de responsabilidade dos pais foram atribuídas para o educador, como: "a responsabilidade de um pai/mãe"; "todas"; "de como seria se estivesse com seu próprio filho"; de "passar segurança, amor, carinho, e por limite adequado". No entanto, dois pais se abstiveram de suas respostas.

Outro questionamento importante para a pesquisa foi se os pais podem contribuir com a escola para o desenvolvimento global (integral), a que doze pais afirmaram poder contribuir apoiando as iniciativas dela, participando e interagindo no dia-a-dia e nas reuniões convocadas e atividades solicitadas. Em contrapartida, um pai declarou que "o governo pode fazer muita coisa, mas não faz" e o outro desabafou dizendo que o filho "por ele ter dificuldade da fala, a escola poderia encaminhá-lo a fonoaudióloga". No relato de dois pais foi colocado que contribuiriam em casa, ajudando o filho e que pais são os principais na educação dos filhos e que compete à família a principal tarefa. Sobre este aspecto, Bock, Furtado e Teixeira (2009, p. 220-221) afirmaram que:

Devido à complexidade da nossa sociedade, a família não dá conta de todo o processo de socialização. Uma outra importante agência de socialização é a escola. Assim como a família, a escola tem um papel conservador, pois também é responsável pela reprodução de normas e valores sociais e, consequentemente, mantedora do contexto social. Já dissemos, quando discutimos a família, que a sociedade apresenta uma gama de valores que permite uma família mais liberal e outra mais conservadora. $\mathrm{O}$ mesmo ocorre com a escola que apesar de sua função de manutenção social poderá ter um sentido crítico e, outras vezes, muito mais conservador do que o esperado pela própria sociedade.

No que se refere à qualidade do ensino, dez pais concordaram que a preparação para a cidadania é uma das tarefas da escola, aspecto já apontado em outros questionamentos, e doze pais acreditam que a educação deve iniciar em casa e que a escola e o professor devem complementar o papel da família. Nove pais 
consideraram que estão adequados os procedimentos que a escola utiliza para avaliar a aprendizagem de seus filhos no decorrer do ano.

Com relação às brincadeiras, seis pais declararam que a escola está esquecendo que estão lidando com crianças e que elas precisam do lúdico para aprender, ou seja, de que o brincar faz parte do processo ensino-aprendizagem na educação infantil. Em contrapartida, um pai fez menção de que, quanto mais brincadeiras acontecerem na escola, menos o meu filho irá aprender. Foi ressaltado por oito pais que, se a escola convidasse os pais para participarem de eventos nos finais de semana, juntamente com os filhos, seria criada a possibilidade de ambos, professores e pais, perceberem o desenvolvimento das crianças.

A respeito deste assunto, Vygotsky (2005) atribui relevante papel ao brincar para a construção do pensamento infantil. A criança, utilizando-se da brincadeira, reproduz o discurso externo e o internaliza, construindo o próprio pensamento e a linguagem, segundo este autor, tem importante papel no desenvolvimento cognitivo da criança à medida que sistematiza suas experiências e ainda colabora na organização dos processos em andamento.

Quanto às tarefas de casa, um pai respondeu que não deveriam ser enviadas, pois a aprendizagem das crianças deve ser da de responsabilidade dos professores; três pais afirmaram que não gostariam de ter que ajudar o filho no dever de casa, afirmando que trabalham o dia todo e que não têm tempo para isso e cinco pais admitiram que o filho aprende mais na escola do que em casa. No entanto, dois pais consideraram que quanto mais dever de casa, mais aprenderão.

Quanto às necessidades pedagógicas e emocionais dos alunos, um pai manifestou que a escola tem a responsabilidade em supri-las e todos os pais admitiram que os professores devem preocupar mais com o desenvolvimento emocional do que com a aprendizagem dos alunos. Curiosamente, dois pais não dão importância para o projeto pedagógico da escola, manifestando-se que o importante é que a escola alfabetize os seus filhos mais rapidamente.

Questionados a respeito da função da escola em educar o aluno, um pai respondeu que a escola que a obrigação de o fazer uma vez que paga para isto. Para quatro pais é importante acrescentar outras necessidades educacionais, tais como: 
"que os professores fossem além da instrução, fosse um pai no sentido literal, olhasse o aluno como um todo"; que se deve ter com as "avaliações, maiores cuidados"; que há a necessidades de que as crianças leiam, entendam e interpretam e que há muita tarefa para casa que não despertam o interesse para a criança, terminando pela mãe ou o pai executando-as para o filho.

\subsubsection{Relações Interpessoais}

As relações interpessoais na escola, no primeiro questionamento os doze pais descreveram o que esperam ouvir dos dirigentes e professores, quando são convidados para uma reunião escolar, qual seja, sobre a aprendizagem e o desenvolvimento do seu filho, mais relevante para eles; três pais elegeram o elogio como o mais importante para ouvir nas reuniões, uma mãe afirmou que "é convidada toda segunda-feira para ouvir sobre o filho", porém, um dos pais demonstrou que aceita críticas com relação ao seu filho.

Indagado sobre o conhecimento do Projeto Pedagógico da escola, doze pais apresentaram o "não" como resposta, sendo que um pai questionou o que seria um projeto pedagógico. Quatro pais declararam que o conhecia, dentre eles três afirmaram que isto era importante para "saber as metas e objetivos da escola"; para "nós pais, estejamos cientes da didática usada pelos professores com os nossos alunos" e "para que a família possa acompanhar os filhos".

Sobre o projeto político-pedagógico, Veiga (2016, p.117-118) afirma que ele “é um instrumento formativo e auxilia a desenvolver uma ação coletiva, porque não se constroem projetos por decretos ou intervenções externas à escola. O projeto edifica-se com o próprio grupo de professores, alunos, pais, funcionários, representantes da comunidade no âmbito da prática pedagógica". Continuando sobre o assunto, Veiga (2016, p.117-118) afirma que:

as rupturas almejadas para a melhoria da qualidade do ensino só atingem seu sentido na prática pedagógica, nas interações vividas entre professores, alunos, pais, funcionários e representantes da comunidade, em suas experiências, seus processos e resultados. A ruptura com a concepção conservadora de educação incide na própria organização do trabalho pedagógico da escola, na vida escolar dos alunos, no que fazem e como o fazem, no que vivem e como vivem. Por outro lado, a ruptura implica condições favoráveis que 
ofereçam recursos necessários, condições e processos para que possa atingir a prática pedagógica em sua essência.

Quanto ao número de reuniões que a escola promove para a família, nove pais acreditam que a instituição oferece o número suficiente, para ficarem a par do desenvolvimento global da criança; seis pais disseram que "não", que a escola precisa oferecer mais reuniões durante o ano letivo e um pai disse que mais ou menos, pois em um ano sente falta de reunião e em outro não, ou seja, que é preciso ter sensibilidade sobre a necessidade de haver reunião na escola.

Sobre o relacionamento escola-pais, dois pais manifestaram-se que ele deve existir, outro pai acredita que a escola é deve ser responsável pela aprendizagem dos filhos e um deles afirmou que é dos pais esta responsabilidade. Quanto à proximidade sócio-pedagógica dos filhos, por meio da realização de projetos, nove pais acreditam que a escola deveria realizá-los em parceria com os pais, um pai não percebe o real sentido desses projetos.

Quanto à participação de reuniões escolares, quatro pais afirmaram que preferem não comparecer às reuniões, para não receberem reclamações sobre os filhos, sendo que um deles sugeriu que ela fosse realizada em sala reservada. Dez pais acreditam que a escola deve desenvolver atividades culturais com as famílias, a fim de que os pais possam trocar experiências sobre o desenvolvimento das crianças.

No que tange ao envio de bilhetes na agenda do meu filho; três pais afirmaram que não concordam com este comportamento da escola, cobrando tarefas, compromissos, dentre outras burocracias escolares. Os pais foram unânimes quanto à parceria da família com os profissionais da escola, pois reconhecem que ela é fundamental para o desenvolvimento global das crianças.

Ainda sobre a relação professor-pais, quatro pais afirmaram que os docentes não estão preparados para compartilhar com os pais as atividades pedagógicas que desenvolvem, limitando-se essa relação à prestação de contas e cobranças.

Os pesquisados ainda apresentaram como necessidades a serem supridas na escolar, que a mesma deve oferecer cursos para os pais, que se deve reestruturar o ensino em todos os sentidos e que haja por parte do governo mais interesse em "mudar esse quadro terrível da educação". 
A escola nesse contexto é vista como responsável juntamente com os pais para a formação da criança. Esse ser humano pequeno, que um dia irá se desenvolver e virá a tornar-se um adulto, necessita da construção do conhecimento, que pode ser vista como uma emergência dos relacionamentos intersubjetivos que retroagem sobre os sujeitos individuais e coletivos que, por sua vez, alimentam as redes construindo novos conhecimentos. Segundo Hernandez (2005), as subjetividades individual e social são construídas na inter-relação do ser humano com seus contextos social e natural, no marco de sua atividade cotidiana, sendo então um produto histórico-cultural.

Toda a construção, condensada na produção cultural (ideológica, espiritual e material) constitui o conjunto de práticas, tradições, crenças, valores, sentimentos, estereótipos, representações etc. que formam o substrato da subjetividade social, no qual a formação do senso comum cotidiano, as manifestações do inconsciente coletivo e a intencionalidade dos sujeitos sociais se expressam os graus de auto-repressão ou autonomia social que possibilitam o contexto. (HERNANDEZ, 2005, p. 83).

Portanto, a criança é um sujeito social ativo, que recebe influência da família, da escola e da sociedade em geral.

\subsubsection{Formação para o trabalho}

Quanto à formação do docente atuar na educação infantil, catorze pais concordaram que os professores devem estar em constante busca de novos conhecimentos e materiais para enriquecer seu trabalho em sala de aula e oito pais acreditam que todos os professores da educação infantil deveriam ser formados em Pedagogia, pois estariam mais bem preparados para o trabalho pedagógico. Entretanto, dez dos pais consideraram que o professor de seu filho está bem preparado para exercer a docência, apesar de frisarem que a comparação entre alunos feita pelo professor entre alunos, traz desmotivação e provoca problemas na frequência escolar. Sobre este aspecto a Lei $n^{0}$ 12.014, de 2009) afirma que:

Art.61: Consideram-se profissionais da educação escolar básica os que, nela estando em efetivo exercício e tendo sido formados em cursos reconhecidos, são: (Redação dada pela Lei $n^{\circ}$ 12.014, de 2009) I - professores habilitados em nível médio ou superior para a docência na educação infantil e nos 
ensinos fundamental e médio; (Redação dada pela Lei $n^{\circ}$ 12.014, de 2009)

Entre os pesquisados, dois pais citaram que a oferta de cursos de aperfeiçoamento para o professor e contratação de um profissional na área de Psicologia são relevantes, a fim de colaborar na solução dos problemas que envolvem o professor e alunos para o sucesso educacional, os mesmos pais, fizeram alusão ao fato de que "alguns professores não sabem dar aula", dando a "impressão que enrolam" e que fazem uso de muitas licenças médicas.

Em se tratando do uso da didática em sala de aulas de educação infantil (THERRIAULT, 1987 apud KISHIMOTO, 2001)) é necessário investigar as concepções de criança que definem o uso de brinquedos e materiais pedagógicos.

Os brinquedos em sala de aula possuem dois usos com significações distintas: o brincar livre para a valorização da socialização e o brincar dirigido, algumas vezes através do uso de jogos educativos, com a finalidade de escolarização ou aquisição de conteúdos. Podem-se adotar dois conceitos de brinquedo: 1. Brinquedo como objeto de suporte da brincadeira, e 2. O brinquedo como objeto de ação lúdica iniciada pela criança tendo motivação intrínseca. (BROUGÈRE, 1995a, 1995b; KISHIMOTO, 1996 apud KISHIMOTO, 2001)).

Cabe aos educadores, no momento do planejamento pedagógico, elaborar o plano de atividades relacionado ao conteúdo que precisa ser passado de forma a integrar o brincar livre com o brincar direcionado. Assim, no momento da avaliação da criança, conforme o art. 31 da LDB (BRASIL.MEC, 1996), "mediante acompanhamento e registro do desenvolvimento das crianças, sem o objetivo de promoção [...]”. Deve-se informar pai e mãe, conviventes ou não com seus filhos, e, se for o caso, os responsáveis legais, sobre a frequência e rendimento dos alunos, bem como sobre a execução da proposta pedagógica da escola e esclarecer eventuais dúvidas sobre a metodologia e a didática usada em sala de aula, conforme o Art. 12 da LDB (BRASIL.MEC, 1996).

Percebe-se, portanto, a grande responsabilidade do profissional da Educação Infantil, que deverá ter um perfil multifacetado para atender às diversas solicitações que a criança exige nessa idade. 


\subsubsection{Realidade Escolar}

Em relação ao que os pais esperam que a escola e que o governo façam pela educação de seus filhos, catorze pais identificaram que é imprescindível investir na estrutura educacional, que melhore a remuneração dos professores, que invistam em inovações tecnológicas, proporcionando qualidade no ensino, tanto para os alunos quanto para os profissionais da educação.

Os pais esperam que devam existir políticas públicas no sentido de fiscalizar as escolas com baixo desempenho, para que estes estabelecimentos, cientes de suas deficiências, preencham as lacunas apontadas, ampliando, portanto, as possibilidades da aprendizagem das crianças.

Conforme Libâneo, Oliveira e Toschi (2005, p.117), sobre o assunto, deve-se “inferir, portanto, que a educação de qualidade é aquela mediante a qual a escola promove, para todos, o domínio dos conhecimentos e o desenvolvimento de capacidades cognitivas e afetivas indispensáveis ao atendimento de necessidades individuais e sociais dos alunos".

Em concordância com este pensamento, o Programa de Capacitação a Distância para Gestores Escolares (PROGESTÃO) (PENIN.; VIEIRA; MACHADO, apud CONSED, 2009, p. 45) afirma que "uma escola voltada para o pleno desenvolvimento do educando valoriza a transmissão de conhecimento, mas também enfatiza outros aspectos: as formas de convivência entre as pessoas, o respeito às diferenças, a cultura escolar".

Quanto à estrutura e funcionamento da escola, seis pais explicitaram que as necessidades da realidade escolar e que deveriam ser supridos são de profissionais nas áreas de saúde, como Nutricionista, Psicólogo e Fonoaudiólogo e na área de ensino como o reforço escolar e aulas de natação. Uma queixa apresentada foi com relação à merenda escolar que deveria ser melhorada principalmente para os alunos que ficam na escola em tempo integral.

\subsubsection{Considerações Finais}


A faixa etária dos participantes variou bastante de 20 anos a 60 anos, o que, entretanto, não fez ocorrer divergência de percepção deste nível de ensino. A formação acadêmica dos pais está representada pela conclusão da educação básica o que vem a demonstrar mais uma vez que os pais de nível econômico mais elevado e, consequentemente, com graduação, matriculam-se os seus filhos em escolas particulares.

Os pais afirmaram também que o papel da escola é muito importante, pois deve ajudar a criança a desenvolver suas habilidades e adquirir conhecimentos, promovendo a sua cidadania e o seu desenvolvimento intelectual.

Quanto à questão da indisciplina, os pais divergiram entre si, uns achando que a solução compete ao educador, inclusive cuidando das crianças como se fossem seus filhos, e outro que competia à família. Deve-se salientar o fato de que alguns pais ainda gostariam que os seus filhos fossem tratados pelos educadores, relataram que "deveria ser como antigamente-castigo, rigor na punição".

Percebeu-se a visão de alguns pais em quererem a reestruturação do sistema educacional a partir das pequenas situações, como melhoria das reuniões escolares com propósitos explícitos, "desarmada em sua política interna" e transparente em suas ações educacionais.

No que se refere às relações interpessoais, considera-se importante salientar que nove pais salientaram a busca de parceria escola-pais para uma educação de qualidade e diferenciada. Um número significativo de pais acredita que a escola deve desenvolver atividades culturais com as famílias, para que haja mais oportunidade de troca de experiência sobre o desenvolvimento dos filhos. Ficou clara a existência de dúvidas, por parte dos pais, com relação aos projetos pedagógicos da escola do seu filho.

Considera-se que, de acordo com o número dos pais que participaram de pesquisa, pode-se estabelecer uma percepção indicativa da situação de algumas escolas públicas do Distrito Federal. 
Os pais encontram-se atentos e querem uma educação de qualidade e diferenciada para os seus filhos. Houve pais que salientaram a importância da parceria entre família-escola-governo.

A preocupação com a estrutura e funcionamento educacional, os quais interferem no desenvolvimento e aprendizagem da criança, não fez com que os pais eximissem sua responsabilidade na formação de seus filhos, mas, entretanto, atribuíram ao governo a liderança quanto à qualidade do sistema de ensino.

Pretende-se divulgar os resultados desta pesquisa em eventos e em periódicos científicos, em nível regional, nacional e internacional. Esses resultados poderão servir de base para reflexões entre profissionais desse nível de ensino e fornecer elementos que contribuam tanto para instituições de educação infantil como para a sociedade que devem buscar uma educação de qualidade e igualitária

\subsection{De escola particular}

O objeto desta pesquisa foi apresentar a percepção dos pais quanto às expectativas e às necessidades da Educação Infantil em escolas particulares do Distrito Federal. As categorias selecionadas foram: caracterização dos participantes da pesquisa; trabalho pedagógico; relações interpessoais; formação para o trabalho e realidade escolar. Considerou-se necessário, para o alcance dos objetivos, questionar aos pais a propósito das principais atribuições do professor; do papel da escola; das atitudes dos docentes; da preparação e da responsabilidade dos professores em relação aos alunos e à qualidade do ensino; da contribuição dos pais ou responsáveis em relação ao desenvolvimento integral da criança; da estrutura e do funcionamento da escola; do relacionamento escola-pais. Os pais encontram-se inteirados do processo educacional dos filhos e participam das atividades propostas pela escola. Acreditam que os professores devam estar em constante aprimoramento para melhorar a qualidade do trabalho pedagógico, inclusive sugerindo que o governo se dedique a esta formação.

\subsubsection{Situando o Assunto}


O tema deste trabalho versa acerca das necessidades e das expectativas da educação infantil e da formação do professor que pretende atuar neste nível de ensino, por intermédio da percepção dos pais da escola particular. Pretende também investigar, diante das mudanças governamentais realizadas nos últimos dez anos, se o profissional que atua na Educação Infantil encontra-se preparado diante da realidade da educação infantil do Distrito Federal.

Compreende-se como educação infantil aquela que atende pedagogicamente o período de vida escolar de crianças com idade entre 0 e 5 anos, isto com a implantação do ensino fundamental de nove anos. Entretanto, este trabalho enfatiza o período de 3 a 5 anos.

De acordo com a Lei de Diretrizes e Bases da Educação Nacional (LDB) 9.394/96 (BRASIL.MEC, 1996), a instituição educacional que atende crianças de 0 a 3 anos é denominada de creche e a que atende crianças de 4 e 5 anos denomina-se infantil.

A Constituição Federal da República de 1988 (BRASIL, 1988) determinou, em seu art. 208, inciso IV, que a educação na faixa etária de 4 e 5 anos é dever do Estado e que essa responsabilidade, então, caberia ao antigo curso normal (nível técnico) ou simplesmente magistério de segundo grau.

Desse modo, o objetivo geral deste trabalho foi investigar, junto aos pais, as expectativas e as necessidades da Educação Infantil verificando-se também a preparação do profissional para atuar nesse nível de ensino. Os objetivos específicos pretenderam:

Investigar junto aos pais as expectativas e as necessidades que emergem da comunidade familiar com relação à Educação Infantil;

Investigar os procedimentos didático-metodológicos utilizados pelos professores e os resultados pedagógicos até então alcançados;

Verificar a opinião dos pais quanto à preparação dos profissionais que atuam na educação infantil; 
Propor alternativas para aperfeiçoar o processo de formação do profissional da Educação Infantil tendo em vista as expectativas da comunidade escolar do Distrito Federal.

\subsubsection{Análise e discussão dos dados: principais resultados}

\subsubsection{Caracterização dos participantes da pesquisa na escola particular}

Os participantes da pesquisa, à exceção de 1 (um), eram do sexo feminino. Percebeu-se que a faixa etária de 8 (oito) pais participantes encontrava-se entre 31 a 40 anos, de 6 (seis) entre 41 a 50 anos e de 4 (quatro) entre 20 a 30 anos.

Quanto à graduação ou escolaridade ( $1^{\circ}$ grau completo, $2^{\circ}$ grau completo, graduação, mestrado e doutorado), 1 (um) dos pais participantes fez apenas o $1^{\circ}$ grau completo, 3 (três) fizeram o $2^{\circ}$ grau completo, 6 (seis) a graduação, 3 (três) pais fizeram especialização, 4 (quatro) o mestrado e 1 (um) o doutorado.

Em relação à profissão, percebeu-se que todos os participantes trabalhavam, estando 11 (onze) envolvidos com profissões relacionadas à educação enquanto o restante exercia profissões diversas como: empresário, cientista, médico, servidora pública, psicóloga e dona de casa.

\subsubsection{O trabalho pedagógico}

A respeito dos atributos que deve ter o professor da Educação Infantil, os entrevistados elencaram várias características essenciais, as quais entendem ser necessárias na formação do perfil profissional desse educador: afetividade, gostar da profissão, ter afinidade com crianças pequenas, ser flexível, ter formação para atuar como professor de Educação Infantil, ser paciente e ter muita atenção a tudo que acontece com as crianças.

Em relação ao papel da escola na formação dos filhos, todos os participantes concordaram que é fundamental para o desenvolvimento dos filhos. Os pesquisados acrescentaram que a escola dá continuidade à educação que a família desenvolve em casa, e que ela é responsável por ensinar regras sociais, preparando as crianças para viverem com responsabilidade, com honestidade, com urbanidade e com respeito ao 
próximo. Em relação a esse aspecto, Libâneo (2013a, p. 16-17) enfatiza que: “o trabalho docente é parte integrante do processo educativo mais global pelo qual os membros da sociedade são preparados para a participação na vida social.”

Os entrevistados opinaram que quando os alunos são indisciplinados os professores devem perguntar para a criança o que aconteceu, saber com clareza a situação ocorrida e explicar que a atitude que ela teve foi inadequada. Caso o fato se repita, aplicar alguma penalidade e avisar a família do ocorrido. Os pais concordaram que é importante que o orientador pedagógico observe e acompanhe esta criança e acreditam que a família deve estar ciente da conduta delas na escola para que em casa possam ajudar. Em síntese, todos os participantes acreditam que o diálogo professor-aluno; aluno-professor; professor-família; família-professor; família-educando; educando-família seja fundamental para ajudar a criança indisciplinada a ajustar-se melhor na escola.

Os participantes apontaram responsabilidades do professor quando ele estiver com as crianças. Eles acreditam que além de ensinar o conteúdo programático, o professor é também responsável pelo aspecto emocional e social da criança, ou seja, com o que ela sente e como se relaciona com os outros. Afirmaram, ainda, caber a ele zelar pela saúde e pelo bem estar das crianças, observando-lhes as necessidades físicas.

Os entrevistados asseguraram que poderiam contribuir para o desenvolvimento integral do filho, apoiando as iniciativas da escola, participando das atividades para as quais fossem convocados, interagindo no dia a dia e indo às reuniões. Além disso, afirmaram que devem contribuir com a escola no acompanhamento das atividades, das tarefas de casa e com os trabalhos sugeridos aos seus filhos a título de complementação da aprendizagem. Para Bock, Furtado e Teixeira (2009 p. 220-221), sobre esse aspecto:

Devido à complexidade da nossa sociedade, a família não dá conta de todo o processo de socialização. Outra importante agência de socialização é a escola. Assim como a família, a escola tem um papel conservador, pois também é responsável pela reprodução de normas e valores sociais e, consequentemente, mantedora do contexto social. Já dissemos, quando discutimos a família, que a sociedade apresenta uma gama de valores que permite uma família mais liberal e outra 
mais conservadora. O mesmo ocorre com a escola que apesar de sua função de manutenção social poderá ter um sentido crítico e, outras vezes, muito mais conservador do que o esperado pela própria sociedade.

No que se refere à qualidade do ensino, os pais entrevistados concordaram que a preparação da cidadania, a complementação do papel exercido pela família é tarefa da escola; que a educação começa em casa e que os procedimentos utilizados no âmbito escolar para avaliar a aprendizagem dos filhos, no decorrer do ano, são adequados. Um terço dos pais acreditou que a escola está "esquecendo" que os filhos são crianças e que precisam do ludismo para aprender, ou seja, que brincar, durante a educação infantil, faz parte do processo ensino-aprendizagem.

A respeito deste assunto, Vygotsky (2005) atribui relevante papel ao ato de brincar na construção do pensamento infantil. A criança, utilizando a brincadeira, reproduz o discurso externo e o internaliza, construindo o próprio pensamento.

Três pais afirmaram que educar os filhos deles é função da escola, pois afinal pagam por isso. Já, onze pais concordaram que a educação começa em casa e a escola e o professor devem complementar o papel da família.

Seis dos pais entrevistados acreditam, também, que se a escola convidasse os pais para participarem de eventos culturais nos finais de semana, juntamente com os filhos, criaria a possibilidade de percepção conjunta e de troca de experiências entre eles e os professores acerca do desenvolvimento das crianças e haveria maior aproximação entre todos, família-alunos-escola, com consequências eficientes ao processo ensino-aprendizagem.

Quanto às tarefas de casa, dois pais entrevistados acreditam que elas sejam necessárias para manter os filhos ocupados, uma vez que o resultado deve ser da responsabilidade dos professores e que o filho aprende mais na escola que em casa. Os participantes acrescentaram à qualidade de ensino a necessidade de o professor estar em constante "busca pelo novo".

\subsubsection{Relações Interpessoais}

As relações interpessoais na escola foram apresentadas de diferentes formas. No primeiro item desta categoria, os entrevistados opinaram a respeito do que 
esperam ouvir dos dirigentes e dos professores quando são convidados para reuniões escolares. Na segunda etapa, os entrevistados responderam perguntas relativas a diversos temas como: o número de reuniões pedagógicas da escola; a família; o Projeto Político-Pedagógico; a convivência das crianças na escola; a responsabilidade do professor; a escola e a realização de projetos em parceria com a família e as reclamações dos filhos.

Quando a família é convidada para reuniões escolares, afirmaram os pais, espera-se que a Direção da escola trate de assuntos relativos ao funcionamento da instituição, apresentando os projetos desenvolvidos pelos professores, propostas de mudanças e melhorias dos serviços educacionais.

Quanto ao número de reuniões que a escola promove para a família, os participantes pesquisados acreditam que a instituição oferece o número suficiente de encontros para ficarem a par do desenvolvimento global da criança; apenas quatro entrevistados disseram que a escola precisa e deve oferecer mais reuniões durante o ano letivo; um entrevistado afirmou que "a quantidade de reuniões deve ser adaptada às necessidades individuais", ou seja, a criança que tem mais dificuldade precisa ser mais assistida pela família.

Os entrevistados afirmaram conhecer o Projeto Pedagógico da escola; uma das mães pesquisadas acredita ser fundamental a família conhecer este projeto, pois, segundo ela, nele encontra-se a "filosofia que irá nortear todo o trabalho a ser desenvolvido pela instituição". Outra mãe entrevistada acredita ser muito importante os pais conhecerem os objetivos propostos pela instituição. Na escola em que o Projeto Pedagógico não é conhecido, um pai afirma que, caso queiram, devem, sim, procurar conhecer esta proposta para que fiquem inteirados do que será trabalhado na rotina escolar. A respeito do projeto político-pedagógico, Veiga (2016, p.117-8) afirma que "é um instrumento formativo e auxilia a desenvolver uma ação coletiva, porque não se constroem projetos por decretos ou intervenções externas à escola. $\mathrm{O}$ projeto edifica-se com o próprio grupo de professores, alunos, pais, funcionários, representantes da comunidade no âmbito da prática pedagógica”. Continuando acerca do assunto, Veiga (2016, p.117-8) afirma que: 
as rupturas almejadas para a melhoria da qualidade do ensino só atingem seu sentido na prática pedagógica, nas interações vividas entre professores, alunos, pais, funcionários e representantes da comunidade, em suas experiências, seus processos e resultados. A ruptura com a concepção conservadora de educação incide na própria organização do trabalho pedagógico da escola, na vida escolar dos alunos, no que fazem e como o fazem, no que vivem e como vivem. Por outro lado, a ruptura implica condições favoráveis que ofereçam recursos necessários, condições e processos para que possa atingir a prática pedagógica em sua essência.

Em relação à convivência das crianças com os colegas na escola, apenas um pai entrevistado acredita que o professor tem responsabilidade sobre esta interação. Quanto ao envio de bilhetes na agenda da criança, para fazer cobranças de tarefas, compromissos e burocracias escolares, 4 (quatro) pais não concordaram.

Quinze dos entrevistados acreditam que a parceria entre a família e os profissionais da escola é entendida como fundamental para o desenvolvimento global das crianças. Apenas 3 (três) entrevistados abordaram que os docentes não estão preparados para compartilhar com os pais as atividades pedagógicas que desenvolvem, limitando a relação professor-família à informação e a cobranças.

Na última questão desta categoria, os participantes deveriam apontar necessidades da escola ainda a serem supridas e apenas 1 (um) pai manifestou-se, afirmando que "o docente que não faz a sua parte está sujeito a cobranças pela atitude omissa"

\subsubsection{Formação para o trabalho}

Nessa categoria foram verificados os itens essenciais que influenciam diretamente a aprendizagem das crianças.

No primeiro aspecto quinze pais concordaram que os professores devem buscar constantemente novos materiais para enriquecer o trabalho em sala. No segundo aspecto, metade dos pais considera que o professor deve estar bem preparado para exercer a docência. No terceiro aspecto, três pais apontaram que se o professor faz comparação entre alunos na sala de aula gera desmotivação para a frequência escolar. Para um entrevistado é fundamental que "a professora não compare os alunos" devendo observá-los continuamente e sempre que possível valorizar lhes as atitudes fazendo comentários construtivos. 
Cinco dos pais entrevistados acrescentaram algumas observações que julgam importantes para o desenvolvimento dos educandos. Uma entrevistada sugeriu a prática de esportes na escola; outro acredita que a escola deve "estimular e proporcionar aos professores aprimoramento constante da prática educacional". Um pai reforçou um aspecto já mencionado no trabalho de que "todos os professores deveriam ter formação em Pedagogia", mas acrescentou que "não quer dizer que seriam, necessariamente, os mais preparados", por terem esta qualificação. Para outro pai é necessário ao docente "permanentemente buscar a reflexão sobre sua prática", propondo estes momentos em reuniões coletivas na própria escola.

O ensino é crítico, segundo Libâneo (2013a, p.100) quando:

Implica objetivos sócio-políticos e pedagógicos, conteúdos e métodos escolhidos e organizados mediante determinada postura frente ao contexto das relações sociais vigentes na prática social. Ele se realiza, no entanto, dentro do processo de ensino. [...] Isso significa que ao professor crítico não basta que denuncie as injustiças sociais, que esteja engajado num sindicato ou partido ou que explicite o caráter ideológico dos conteúdos escolares. É preciso, antes de tudo, que dê conta de traduzir objetivos sócio-políticos e pedagógicos em formas concretas de trabalho docente que levem ao domínio sólido e duradouro de conhecimentos pelos alunos, que promovam a ampliação de suas capacidades mentais, a fim de que desenvolvam o pensamento independente, a coragem de duvidar e, com isso, ganhem convicções pessoais e meios de ação prática nos processos de participação democrática da sociedade.

Portanto, o professor deve ter claro que o ensino tem que levar em consideração não apenas as características biológicas da criança, mas também todas as variáveis que interferem no ensino, tais como os aspectos sociais, econômicos, políticos e culturais.

\subsubsection{Realidade Escolar}

Em relação ao que os pais esperam que a escola e o governo façam pela educação de seus filhos, de maneira geral os pais pesquisados identificaram as seguintes funções da escola: qualidade no ensino, segurança para os filhos, bons recursos para o ensino e investimento na formação dos professores. Em relação ao governo foi salientado que ele deve incentivar a educação por meio das mais 
diferentes formas e estendê-la para todos e, assim, preparar os filhos para o mercado de trabalho. Conforme Libâneo, Oliveira e Toschi (2005, p.117), neste aspecto:

Devemos inferir, portanto, que a educação de qualidade é aquela mediante a qual a escola promove, para todos, o domínio dos conhecimentos e o desenvolvimento de capacidades cognitivas e afetivas indispensáveis ao atendimento de necessidades individuais e sociais dos alunos.

Doze pais afirmaram estarem satisfeitos com as condições pedagógicomateriais da escola; quatorze acreditam que a escola onde os filhos estudam, apresenta condições necessárias ao processo de ensino e aprendizagem.

Segundo 1 (um) dos entrevistados, a escola deve ser "um ambiente que proporcione adequado desenvolvimento das diferentes áreas do conhecimento", explorando todo o potencial da criança. Os participantes concordaram que a formação docente inicial e continuada são elementos essenciais para a melhoria da qualidade do ensino.

Os pais esperam que a escola seja fonte de educação de qualidade, com profissionais bem preparados e dedicados ao ensino, devendo haver investimento do governo em cursos gratuitos para a atualização do corpo docente. São necessárias políticas públicas que fiscalizem as escolas com baixo desempenho, para que elas, cientes das próprias deficiências, superem as lacunas apontadas.

Em concordância com este pensamento, o Progestão ((PENIN.; VIEIRA; MACHADO apud CONSED, 2009, p. 45) afirma que "uma escola voltada para o pleno desenvolvimento do educando valoriza a transmissão de conhecimento, mas também enfatiza outros aspectos: as formas de convivência entre as pessoas, o respeito às diferenças, a cultura escolar”.

A escola deve preparar o indivíduo para a vida e para o mercado de trabalho, concordou 1 (uma) participante, afirmando, ainda, que "deve preparar a filha para que no futuro ela exerça uma boa profissão". Para outra entrevistada, devem existir escolas profissionalizantes, que possibilitem a formação para o trabalho e a continuidade dos estudos. 1 (um) dos entrevistados posicionou-se a respeito do assunto violência dentro da escola, ambiente que para ele deve ser seguro, com professores presentes nos diversos espaços físicos e nos mais variados momentos e 
acredita que a promoção da prática de esportes seja saída para o problema da violência na escola.

No site do Ministério da Educação (2020) há textos a respeito do Fundo ProInfầncia, os quais comprovam que "crianças que começam a frequentar a escola antes dos seis anos de idade têm mais chances de concluir o nível superior e que o Plano de Desenvolvimento da Educação - PDE - pretende garantir ensino público de qualidade para atender estudantes dessa faixa etária”.

Em relação ao governo, os entrevistados concordaram que é competência de o Estado melhorar as condições de ensino promovendo políticas públicas que valorizem os profissionais da educação e que garantam, nos espaços escolares, a formação continuada do professor. Com profissionais valorizados e qualificados para o exercício do magistério, a educação escolar terá qualidade e atenderá os anseios da população atendida.

\subsubsection{Considerações finais}

Observou-se coerência, clareza e objetividade nas respostas dos pais e resultado satisfatório quanto ao envolvimento deles com a educação infantil. Demonstraram atenção com o que ocorre na escola e certo conhecimento tanto em relação aos aspectos administrativos quanto aos aspectos pedagógicos.

A pesquisa indica que os pais de alunos das escolas particulares estão de certa forma inteirados do processo educacional dos filhos e participam das atividades propostas pela escola. Eles acreditam que a escola pode aproximá-los mais dos professores, promovendo encontros extras e, assim, melhorando a educação das crianças.

É primordial para os pais entrevistados que os professores de seus filhos estejam em constante aprimoramento para melhorar cada vez mais a qualidade do trabalho pedagógico, inclusive sugerindo que o governo se dedique a esta formação.

Considera-se que com o número de pais que participaram da pesquisa pode-se estabelecer percepção indicativa da situação da educação infantil no Distrito Federal. Esta parte é de uma pesquisa maior, a qual abrangerá também a participação de pais 
de escolas públicas e de professores, sendo estes últimos tanto de escolas públicas quanto de escolas particulares. Vale ressaltar que já foram realizadas pesquisas com gestores das escolas públicas e das escolas particulares. Todos esses dados reunidos aprofundaram os resultados da pesquisa uma vez que se pretende, ao final, obter resultados contributivos para melhoria do processo de formação do educador no Distrito Federal e a divulgação dos resultados em eventos e em periódicos científicos, em nível regional, nacional e internacional.

Esses resultados poderão servir de base para reflexões entre profissionais desse nível de ensino e fornecer elementos que contribuam com as instituições de educação infantil abrindo oportunidades para a continuação dos estudos, levando a novos projetos, seminários, fóruns e debates. 


\section{CONCLUSÕES}

Chega-se nas considerações finais ou, quem sabe, em uma finalização provisória, pois a educação apresenta um universo dinâmico e real que vive em mudanças e, dentro dela, a Educação Infantil. Esta fase da educação é repleta de descobertas e desafios constantes que conduzem a vislumbrar um mundo de ensinamentos, evoluções e construção do conhecimento.

As bases e os fundamentos vigentes sobre as Políticas Públicas e Legislação no país, a respeito da Educação Infantil, permitem enfatizar que há toda uma preocupação com a criança, seus direitos e sua forma de aprender. Também, com a sua socialização, sua afetividade e a construção de sua moral. Tudo isto, pode ser percebido nos documentos que enfatizam a busca da equidade do ingresso e da aprendizagem dos alunos, a parte pedagógica, a gestão das escolas e a participação dos pais.

Assim, percebe-se que o ato de ensinar e de aprender são ações que surgem e acontecem em uma dimensão real, mas que nem sempre se pode claramente tornálos objetivas e palpáveis, porque este universo conduz a possibilidades e limites em uma produção diferenciada de sentidos. Não é possível também dissociar o cuidar do educar, considerados eixos centrais que caracterizam e são essenciais na educação, pois eles são imprescindíveis e se complementam.

Os dados e resultados apresentados falam por si só e são capazes de explicitar a verdadeira realidade da educação Infantil em um determinado tempo e espaço desta pesquisa e, ainda, pelos vários segmentos investigados nas escolas.

No decorrer da pesquisa, da coleta, da análise e dos resultados percebeu-se que foi possível articular o processo de coleta de dados com os objetivos que envolveram o estudo. Ao mesmo tempo, foi desafiador elaborar uma síntese reflexiva e crítica das especificidades teóricas com as práticas, para a construção dos saberes.

Após estes resultados, as mudanças sugeridas sobre a gestão escolar, a coordenação pedagógica, os professores e as famílias podem contribuir para desvendar e transformar a Educação Infantil. 
Nesse sentido, o planejamento dos gestores, dos coordenadores pedagógicos e dos professores devem ser pensados e (re) significados, percebendo seus objetivos, ações, metodologias diversificadas e avaliações condizentes com o desenvolvimento das crianças. Também, que devem sempre estar dispostos a buscar a formação continuada.

De acordo com as escolas particulares e públicas elas realizam trabalhos com qualidade, mas os participantes da pesquisa revelaram o desejo de repensar os seus papéis, de romper com modelos instalados e ampliar e criar condições para uma ação mais reflexiva, tanto nas intervenções dos gestores, quanto dos docentes, dos discentes e dos familiares.

A escola e seus integrantes, nas questões relacionadas à gestão, aos professores e à família, nas escolas particulares e públicas, são sempre pressionados para mudanças, em um processo de construção contínuo.

Os pais são essenciais nos primeiros ensinamentos educacionais dos seus filhos e devem acompanhar de perto a evolução das crianças no aspecto educacional. Percebeu-se, que os pais estão atentos, conscientes e sabem que devem participar ativamente da proposta pedagógica da escola, opinando e sugerindo o que for necessário de forma dialógica e coletiva.

Sabe-se que há muito a fazer pela educação no país e a tarefa não é fácil para gestores, professores e famílias, porém a qualidade do que se faz é necessária. É preciso continuar explorando os saberes e aprimorar o fazer, pois o caminho é amplo.

Espera-se que esta leitura tenha sido produtiva, prazerosa e que desencadeie olhares e práticas que possibilitem o alcance do sucesso de todos os profissionais envolvidos na Educação Infantil. 


\section{REFERÊNCIAS}

AGUIAR, Beatriz Carma Lima de. A instituição creche: apontamentos sobre sua história e papel. Nuances Vol. VII. Setembro de 2009; p. 30-35.

ALMEIDA, L. R. A dimensão relacional no processo de formação docente: uma abordagem possível. In: BRUNO, Eliane Bambini Gorgueira (Org.). O coordenador pedagógico e a formação docente. 2. ed. São Paulo: Loyola, 2009.

AZEVEDO, Fernando et al. A reconstrução educacional no Brasil: ao povo e ao governo; manifesto dos pioneiros da Educação Nova. São Paulo: Nacional, 1932.

BOCK, A. M. B.; FURTADO, O.; TEIXEIRA, M. de L. T. Psicologias: uma introdução ao estudo de Psicologia. 13. ed. São Paulo:

Saraiva, 2009.

BRASIL. Constituição da República Federativa do Brasil de 1988. Brasília: Senado Federal: Centro Gráfico, 1988.

Emenda Constitucional $n^{\circ} 59$ de 2009 e a educação infantil: impactos e perspectivas. Brasil: Presidência da República, 2011.

BRASIL.MEC. Fundo pró-infância. Disponível em:

$<$ https://www.fnde.gov.br/index.php/pesquisa?searchword=crian\%C3\%A7as\%20qu e\%20come\%C3\%A7am\&searchphrase=all> . Acesso em: 12 fev. 2020.

.. Base Nacional Comum Curricular. Brasília: MEC, 2017. Disponível em: <htpp://basenacionalcomum.mec.gov.br/a-base>. Acesso em: $01 \mathrm{dez} .2019$.

Ministério da Educação. Lei nº. 9394, de 20 de dezembro de 1996 (LDB). Estabelece as diretrizes e bases da educação nacional. Brasília: Senado, 1996.

Lei n. 8.069, de 13 de julho de 1990. Dispõe sobre o Estatuto da Criança e do Adolescente e dá outras providências. Diário Oficial [da] República Federativa do Brasil, Brasília, DF, 16 jul. 1990. Disponível em: <http://www.planalto.gov.br/ccivil_03/LEIS/L8069.htm\#art266>. Acesso em: 29 dez. 2019.

. Lei n.13.005, de 25 de junho de 2014. Aprova o Plano Nacional de Educação - PNE e dá outras providências. Diário Oficial da União, Brasília, DF., 26 jun. 2014. Disponível em: <https://www.planalto.gov.br/ccivil03/ato20112014/2014/lei/l13005.htm>. Acesso em: 29 dez. 2019.

Lei n. 13.257, de 8 de março de 2016. Marco Legal da Primeira Infância. Disponível em: <http://www.planalto.gov.br/ccivil_0_ato20152018/2016/lei/l13257.htm>. Acesso em: 29 dez. 2019. 
. Lei $n$. 12.796, de 4 de abril de 2013. Altera a Lei n ${ }^{\circ}$ 9.394, de 20 de dezembro de 1996, que estabelece as diretrizes e bases da educação nacional, para dispor sobre a formação dos profissionais da educação e dar outras providências Disponível em: <http://www.planalto.gov.br/ccivil_03/_Ato20112014/2013/Lei/L12796.htm>. Acesso em: 02 de mar. 2020.

Lei $n^{\circ} 12.014$ de 06 de agosto de 2009. Altera o art. 61 da Lei no 9.394, de 20 de dezembro de 1996, com a finalidade de discriminar as categorias de trabalhadores que se devem considerar profissionais da educação. Disponível em: <http://www.planalto.gov.br/ccivil_03/_ato2007-2010/2009/lei/l12014.htm>. Acesso em: 17 mar. 2020.

CAMPANHA NACIONAL PELO DIREITO À EDUCAÇÃO. Plano Nacional de Educação: 5 anos de descumprimento. 2019. São Paulo. Disponível em:

$<$ https://educacaointegral.org.br/wpcontent/uploads/2019/05/RelatorioMetasEstrategias_PNE_5Ano_Campanha_20191.pdf>. Acesso em: 29 fev. 2020.

CORRÊA, B. C. A educação infantil. In: Organização do ensino no Brasil: níveis e modalidades na Constituição Federal e na LDB. OLIVEIRA, R. P. de; ADRIÃO, T. (Org.). 2. ed. São Paulo: Xamã, 2007.

FREIRE, P. Pedagogia da Autonomia: saberes necessários à prática docente. 43. ed. RJ: Paz e Terra, 2011.

FONSECA, Claudia. Da circulação de crianças à adoção internacional: questões de pertencimento e posse. cadernos pagu 26 (2006): 11-43.

GOMES, G. M. P. A família e processo de ensino e aprendizagem. Revista do Curso de Pedagogia, Brasília, v. 1, n. 1, p. 7-10, jul./dez. 2002.

GONZÁLEZ REY, F. Pesquisa qualitativa e subjetividade: os processos de construção da informação. São Paulo: Thomson, 2007.

GOULART, Iris Barbosa. Piaget: experiências básicas para utilização pelo professor. 21. ed. Petrópolis: Vozes, 2005.

HERNANDEZ O. D’A. Subjetividade e complexidade: processos de construção e transformação individual e social. In: GONZÁLEZ REY, F. Subjetividade, complexidade e pesquisa em psicologia. São Paulo: Thomson Pioneira, 2005.

KISHIMOTO, Tizuko Morchida. Jogos Tradicionais Infantis. Educação e Pesquisa, São Paulo, v.27, n.2, p.229-245, jul./dez. 2001

LIBÂNEO, J. C.; OLIVEIRA J. F.; TOSCHI M. S. Educação escolar: políticas estrutura e organização. 10. ed. São Paulo: Cortez, 2012. (Coleção Docência em Formação). 
LIBÂNEO, J. C. Didática. 2 ed. São Paulo: Cortez, 2013a.

Organização e gestão da escola: teoria e prática. 5. ed. Goiânia: Alternativa, 2013b.

MARQUES, C. M.; PEGORARO, L.; SILVA, E. T. da. Do assistencialismo à Base Nacional Comum Curricular (BNCC): movimentos legais e políticos na Educação Infantil. Revista Linhas. Florianópolis, v. 20, n. 42, p. 255-280, jan./abr. 2019.

MARTINEZ, A. M.; TACCA, M. C. V. R. (Org.). A Complexidade da Aprendizagem: destaque ao Ensino Superior. Campinas: Alínea, 2010.

MORETTINI, M. T. Professoras de Educação Infantil: personagens que se constituem no movimento de suas trajetórias. Campo Grande: UFMS, 2000.

MORGAN, Dimas et al. As políticas Públicas no contexto da educação infantil brasileira. Construção Psicopedagógica. v22 n23: 51-58. Disponível em:

<http://pepsic.bvsalud.org/pdf/cp/v22n23/04.pdf>. Acesso em: 29 dez. 2019.

NÓVOA, A. (Coord.). Os professores e sua formação. 2. ed. Lisboa: Dom Quixote/IIE, 1995.

NUNES, Débora RP. Teoria, pesquisa e prática em Educação: a formação do professor-pesquisador. Educação e Pesquisa 34.1 (2008): 97-107.

OLIVEIRA, Zilma de Moraes Ramos de. Educação Infantil: fundamentos e métodos. SP: Cortez, 2014.

ONU. Resolução n. $^{\circ} 1386$ (XIV), de 20 de novembro de 1959. Disponível em: <https://www.dge.mec.pt/sites/default/files/ECidadania/Docs_referencia/declaracao_ universal_direitos_crianca.pdf>. Acesso em: 29 fev.2020.

PENIN, S. T. S.; VIEIRA S. L.; MACHADO M. A. M. l. Progestão: como articular a função social da escola com as especificidades e as demandas da comunidade? In: CONSED. Brasília: Consed, 2009. (Módulo 1).

PERRENOUD, P. Práticas pedagógicas, profissão docente e formação. Lisboa: Dom Quixote, 1995.

PIAGET, Jean. Seis estudos de psicologia. Tradução Maria Alice Magalhães D’ Amorim e Paulo Sergio Lima Silva. 24. ed. Rio de Janeiro: Forense Universitária, 2003.

PINTO, C. B. G. C. A formação continuada do professor e o sucesso do processo ensino-aprendizagem. Universitas FACE, Brasília, v.2, n.1, p.47-52, jan./jun. 2005. 
REIS, S. D. S.; CUSTÓDIO, A. V. Fundamentos históricos e principiológicos do direito da criança e do adolescente: bases conceituais da teoria da proteção integral. Justiça do Direito. v. 31, n. 3, p. 621-659, set./dez. 2017.

SAVIANI, D. Formação de Professores: aspectos históricos e teóricos do problema no contexto brasileiro. Revista Brasileira de Educação, v. 14, n. 40, jan./ abr. 2009.

SOUZA, M. de F. G. de. A aprendizagem, desenvolvimento e trabalho pedagógico na educação infantil: significados e qualidades. In: TACCA, M. C. V. R. (Org.). A aprendizagem e o trabalho pedagógico. Campinas: Alínea, 2008.

VEIGA, I. P. A. Quem sabe faz a hora de construir o projeto político-pedagógico. Campinas: Papirus, 2016.

VYGOTSKY, L. S. A Formação Social da Mente. São Paulo: Martins Fontes, 2010. Pensamento e Linguagem. São Paulo: Martins Fontes, 2005.

WECHSLER, S. M. Criatividade: descobrindo e encorajando. São Paulo: Livro Pleno, 2003. 